\title{
Asymmetric [4 + 3] Cycloadditions Between Benzofuranyldiazoacetates and Dienes: Formal Synthesis of (+)- Frondosin B
}

\author{
Jeremy P. Olson and Huw M. L. Davies* \\ Department of Chemistry, University of Buffalo, The State University of New \\ York, Buffalo, New York 14260-3000
}

Supporting Information

Experimental Procedures

S-2 - S-14

Spectral Data

S-15 - S-26 
General: Reagents were purchased at the highest commercial quality and used without further purification unless stated otherwise. Analytical thin layer chromatography was performed on Whitman silica gel plates using UV light unless stated otherwise. Flash column chromatography was performed on E. Merck silica $60 .{ }^{1} \mathrm{H}$ NMR spectra were recorded on Varian Nuclear Magnetic Resonance spectrometers at 300, 400, or 500 $\mathrm{MHz}$. Data is presented as follows: chemical shift (in ppm on the scale relative to $\mathrm{H} 7.26$ for chloroform protons), multiplicity $(\mathrm{s}=$ singlet, $\mathrm{d}=$ doublet, $\mathrm{t}=$ triplet, $\mathrm{q}=$ quartet, $\mathrm{m}=$ multiplet, $d d=$ doublet of doublets), coupling constant $(\mathrm{J} / \mathrm{Hz})$, and intergration. ${ }^{13} \mathrm{C}$ spectra were recorded at 74.45 or $125 \mathrm{MHz}$ and all chemical shift values are reported in ppm on the $\delta$ scale, with an internal reference of $\delta \mathrm{C} 77.0$ for $\mathrm{CDCl}_{3}$. Infrared spectra were obtained on a Nicolet Impact 420 FT-IR spectrometer. Mass spectra were recorded on a Hewlett-Packard GC-MS system using LC-MS (ESI). High-resolution mass spectra were obtained from the Mass Spectrometry Facility at the University of Buffalo, The Sate University of New York. Elemental analyses were determined by Atlantic Microlab, Inc., Norcross, GA. Melting points are uncorrected and optical rotations were measured at the sodium $D$ line $(589 \mathrm{~nm}$ ) and reported as follows: concentration (c in $\mathrm{g} / 100 \mathrm{~mL}$ ), and solvent $\left(\mathrm{CHCl}_{3}\right)$. Enantiomeric excess was determined by Varian ProStar high performance liquid chromatography (HPLC) using chiral analytical columns as stated. All moisture sensitive reactions were performed using glassware flame dried under vacuum, and under an argon atmosphere. 


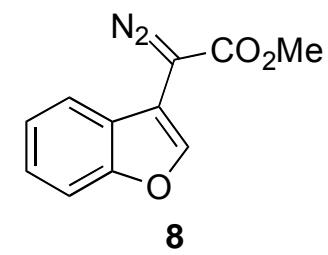

Methyl 2-(benzofuran-3-yl)acetate $\quad(2.23 \quad \mathrm{~g}, \quad 11.7 \quad \mathrm{mmol}), \quad$ and paraacetamidobenzenesulfonyl azide (p-ABSA) $(3.52 \mathrm{~g}, 14.7 \mathrm{mmol})$ were dissolved in acetonitrile $(35 \mathrm{~mL})$ and cooled to $0{ }^{\circ} \mathrm{C}$. 1,8-Diazobicyclo[5.4.0]undec-7-ene (DBU) (3.56 $\mathrm{g}, 23.5 \mathrm{mmol}$ ) was added in one portion and the reaction was stirred at $0{ }^{\circ} \mathrm{C}$ for $1 \mathrm{~h}$, the ice bath was removed and the reaction was stirred 3 additional $\mathrm{h}$ at room temperature. The reaction was poured into saturated ammonium chloride and extracted into diethyl ether. The combined organic layers were washed with brine then dried over $\mathrm{MgSO}_{4}$, filtered and concentrated to obtain the crude product. The crude material was purified by column chromatography (silica gel, 9:1 petroleum ether;diethyl ether) to obtain $\mathbf{8}$ as an orange solid in $67 \%$ yield $(1.69 \mathrm{~g})$. $\mathrm{mp} 82-83^{\circ} \mathrm{C}$; FTIR (neat): 2097, 1714, 1294, 1263 $\mathrm{cm}^{-1} ;{ }^{1} \mathrm{H}$ NMR $\left(500 \mathrm{MHz}, \mathrm{CDCl}_{3}\right) \delta 3.93(\mathrm{~s}, 3 \mathrm{H}), 7.29(\mathrm{t}, 1 \mathrm{H}), 7.38(\mathrm{t}, 1 \mathrm{H}), 7.54(\mathrm{~m}, 2 \mathrm{H})$, $8.02(\mathrm{~s}, 1 \mathrm{H},) ;{ }^{13} \mathrm{C}$ NMR $\left(75 \mathrm{MHz}, \mathrm{CDCl}_{3}\right) \delta 166.1,154.8,141.5,124.9,124.3,122.9$, 118.5, 111.9, 103.7, 52.3; Anal. Calcd for $\mathrm{C}_{11} \mathrm{H}_{8} \mathrm{~N}_{2} \mathrm{O}_{3}$ : C, 61.11; $\mathrm{H}, 3.73 ; \mathrm{N}, 12.96$. Found: C, 61.22; H, 3.74; N, 12.62 .

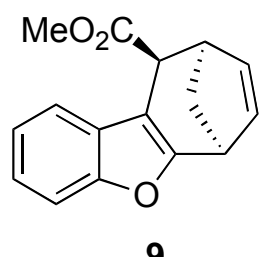

Cyclopentadiene $(459 \mathrm{mg}, 6.94 \mathrm{mmol})$ and $\mathrm{Rh}_{2}(\mathrm{~S}-\mathrm{DOSP})_{4}(8.7 \mathrm{mg}, 0.005 \mathrm{mmol})$ were dissolved in toluene $(7 \mathrm{~mL})$ and cooled to $-78{ }^{\circ} \mathrm{C}$ in a dry ice/acetone bath. Methyl 2(benzofuran-3-yl)diazoacetate 8 (100 mg, $0.461 \mathrm{mmol})$ was dissolved in toluene $(3 \mathrm{~mL})$ and added via syringe pump over $1 \mathrm{~h}$. The reaction was stirred for $16 \mathrm{~h}$ while being warmed slowly to room temperature. The reaction was then heated to reflux $\left(110^{\circ} \mathrm{C}\right)$ for 
one $\mathrm{h}$. The solvent was then removed under reduced pressure and the diastereomeric excess $(>94 \%)$ was obtained (determined by ${ }^{1} \mathrm{H}$ NMR of crude reaction mixture). The residue was purified by column chromatography (silica gel, diethyl ether: pentane $=1: 9$ ) to obtain 9 as a colorless oil in $83 \%$ yield $(98 \mathrm{mg}) \cdot[\alpha]_{\mathrm{D}}{ }^{20}=-215.3^{\circ}\left(\mathrm{c} \mathrm{1.0}, \mathrm{CHCl}_{3}\right)$; FTIR (neat): 2948, 1705, 1604, 1454, 1296, $1237 \mathrm{~cm}^{-1} ;{ }^{1} \mathrm{H}$ NMR (500 MHz, $\left.\mathrm{CDCl}_{3}\right) \delta 2.17$ (d, $1 \mathrm{H}, \mathrm{J}=11 \mathrm{~Hz}), 2.26(\mathrm{~m}, 1 \mathrm{H}), 3.37(\mathrm{~d}, 1 \mathrm{H}, \mathrm{J}=2.5 \mathrm{~Hz}), 3.73(\mathrm{~d}, 1 \mathrm{H}, \mathrm{J}=1.5 \mathrm{~Hz}), 3.85(\mathrm{~s}$, 3H,), $5.32(\mathrm{~d}, 1 \mathrm{H}, \mathrm{J}=4.5 \mathrm{~Hz}), 5.71(\mathrm{~m}, 1 \mathrm{H}), 6.67(\mathrm{~m}, 1 \mathrm{H}), 6.86(\mathrm{~d}, 1 \mathrm{H}, \mathrm{J}=8.0 \mathrm{~Hz}), 6.93$ $(\mathrm{m}, 1 \mathrm{H}), 7.27(\mathrm{~m}, 1 \mathrm{H}), 8.24(\mathrm{~d}, 1 \mathrm{H}, J=8 \mathrm{~Hz}) ;{ }^{13} \mathrm{C} \quad \mathrm{NMR}\left(75 \mathrm{MHz}, \mathrm{CDCl}_{3}\right) \delta 166.1(\mathrm{C})$, $163.2(\mathrm{C}), 145.9(\mathrm{CH}), 145.2(\mathrm{C}), 131.7(\mathrm{CH}), 131.1(\mathrm{C}), 128.2(\mathrm{CH}), 127.3(\mathrm{CH}), 124.9$ (C), $121.2(\mathrm{CH}), 110.5(\mathrm{CH}), 83.0(\mathrm{CH}), 51.5\left(\mathrm{CH}_{3}\right), 44.1(\mathrm{CH}), 41.9\left(\mathrm{CH}_{2}\right), 41.9(\mathrm{CH})$; LRMS (EI) m/z (relative intensity): 254.1 (67); HRMS (EI) Calcd for $\left[\mathrm{C}_{16} \mathrm{H}_{12} \mathrm{O}_{3}\right] 254.0937$, Found 254.0941; Anal. Calcd for $\mathrm{C}_{16} \mathrm{H}_{12} \mathrm{O}_{3}$ : C, 75.57; $\mathrm{H}, 5.55$. Found: $\mathrm{C}, 75.17 ; \mathrm{H}, 5.60$; HPLC analysis: ee >98\% (OD-H column, 1\% i-PrOH in hexanes, $1 \mathrm{~mL} / \mathrm{min}, \lambda=254 \mathrm{~nm}$, $t_{R}=6.13$ min, minor; 7.02 min, major).

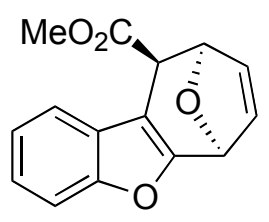

10

Furan $(473 \mathrm{mg}, 6.94 \mathrm{mmol})$ and $\mathrm{Rh}_{2}(\mathrm{~S}-\mathrm{DOSP})_{4}(8.7 \mathrm{mg}, 0.005 \mathrm{mmol})$ were dissolved in toluene $(7 \mathrm{~mL})$ and cooled to $-78{ }^{\circ} \mathrm{C}$ in a dry ice/acetone bath. Methyl 2-(benzofuran-3yl)diazoacetate 8 (100 mg, $0.461 \mathrm{mmol})$ was dissolved in toluene $(3 \mathrm{~mL})$ and added via syringe pump over $1 \mathrm{~h}$. The reaction was stirred for $16 \mathrm{~h}$ while being allowed to warm slowly to room temperature. The solvent was then removed under reduced pressure and the diastereomeric excess $\left(>94 \%\right.$ ) was obtained (determined by ${ }^{1} \mathrm{H}$ NMR of crude reaction mixture). The residue was purified by column chromatography $\left(\mathrm{SiO}_{2}\right.$, diethyl ether:pentane $=1: 9)$ to obtain 10 as a colorless oil in $92 \%$ yield $(109 \mathrm{mg}) \cdot[\alpha]_{D}{ }^{20}=-233.9^{\circ}$ 
(c 1.0, $\mathrm{CHCl}_{3}$ ); FTIR (neat): 2951, 1711, 1605, 1471, 1324, $1273 \mathrm{~cm}^{-1} ;{ }^{1} \mathrm{H}$ NMR (500 $\left.\mathrm{MHz}, \mathrm{CDCl}_{3}\right) \delta 3.84(\mathrm{~s}, 3 \mathrm{H}), 5.22(\mathrm{~s}, 1 \mathrm{H}), 5.39(\mathrm{~d}, 1 \mathrm{H}, \mathrm{J}=5.5 \mathrm{~Hz}), 5.64(\mathrm{dd}, 1 \mathrm{H}, \mathrm{J}=6.0$ $\mathrm{Hz}, 1.5 \mathrm{~Hz}), 5.84$, (dd, 1H, J = 6.0 Hz, 1.5Hz), $6.85(\mathrm{~m}, 2 \mathrm{H}), 6.96(\mathrm{t}, 1 \mathrm{H}), 7.30(\mathrm{~m}, 1 \mathrm{H})$, $8.33(\mathrm{~d}, 1 \mathrm{H}, \mathrm{J}=7.5 \mathrm{~Hz}) ;{ }^{13} \mathrm{C}$ NMR $\left(75 \mathrm{MHz} \mathrm{CDCl}_{3}\right) \delta 164.4(\mathrm{C}), 163.4(\mathrm{C}), 145.9(\mathrm{C})$, $143.9(\mathrm{CH}), 132.6(\mathrm{CH}), 127.9(\mathrm{CH}), 126.8(\mathrm{C}), 125.2(\mathrm{CH}), 124.2(\mathrm{C}), 121.7(\mathrm{CH}), 110.8$ $(\mathrm{CH}), 79.8(\mathrm{CH}), 78.1(\mathrm{CH}), 77.5(\mathrm{CH}), 51.6\left(\mathrm{CH}_{3}\right)$; LRMS (EI) m/z (relative intensity): 255.8 (19); HRMS (EI) calcd. for $\left[\mathrm{C}_{15} \mathrm{H}_{12} \mathrm{O}_{4}\right]$ 256.0730, Found: 256.0730. HPLC analysis: ee $96 \%$ (OJ column, 0.3\% i-PrOH in hexanes, $1 \mathrm{~mL} / \mathrm{min}, \lambda=254 \mathrm{~nm}, \mathrm{t}_{\mathrm{R}}=19.05 \mathrm{~min}$, major; 23.49 min, minor);

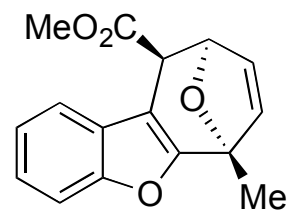

11

2-Methyl Furan $(1.14 \mathrm{~g}, 13.88 \mathrm{mmol})$ and $\mathrm{Rh}_{2}(\mathrm{~S}-\mathrm{DOSP})_{4}(17.4 \mathrm{mg}, 0.009 \mathrm{mmol})$ were dissolved in toluene $(10 \mathrm{~mL})$ and cooled to $-78{ }^{\circ} \mathrm{C}$ in a dry ice/acetone bath. Methyl 2(benzofuran-3-yl)diazoacetate 8 (200 mg, $0.931 \mathrm{mmol})$ was dissolved in toluene $(6 \mathrm{~mL})$ and added via syringe pump over $1 \mathrm{~h}$. The reaction was stirred for $16 \mathrm{~h}$ while being allowed to warm slowly to room temperature. The solvent was then removed under reduced pressure and the diastereomeric excess (>94\%) was obtained (determined by ${ }^{1} \mathrm{H}$ NMR of crude reaction mixture). The residue was purified by column chromatography $\left(\mathrm{SiO}_{2}\right.$, diethyl ether:pentane $\left.=1: 9\right)$ to obtain 11 as a white solid in $83 \%$ yield $(208 \mathrm{mg})$. $[\alpha]_{D}{ }^{20}=-291.2^{\circ}\left(c 1.0, \mathrm{CHCl}_{3}\right) ; \mathrm{mp}=72^{\circ} \mathrm{C} ; \mathrm{FTIR}$ (neat): 2978, 2951, 1716, 1616, 1455, 1268, $1241 \mathrm{~cm}^{-1} ;{ }^{1} \mathrm{H}$ NMR (500 MHz, $\left.\mathrm{CDCl}_{3}\right) \delta 1.83$ (s, 3H), 3.86 (s, 3H), $5.09(\mathrm{~s}, 1 \mathrm{H})$, $5.25(\mathrm{~s}, 1 \mathrm{H}), 5.69(\mathrm{~d}, 1 \mathrm{H}, \mathrm{J}=6.0 \mathrm{~Hz}), 6.78(\mathrm{dd}, 1 \mathrm{H}, \mathrm{J}=5.0 \mathrm{~Hz}, 1.5 \mathrm{~Hz}), 6.89,(\mathrm{~d}, 1 \mathrm{H}, \mathrm{J}=$ $8.5 \mathrm{~Hz}), 6.98(\mathrm{t}, 1 \mathrm{H}),, 7.32(\mathrm{~m}, 1 \mathrm{H}), 8.35(\mathrm{~d}, 1 \mathrm{H}, \mathrm{J}=7.5 \mathrm{~Hz}) ;{ }^{13} \mathrm{C} \quad \mathrm{NMR}\left(75 \mathrm{MHz}, \mathrm{CDCl}_{3}\right)$ ठ $164.5(\mathrm{C}), 163.3(\mathrm{C}), 147.5(\mathrm{C}), 143.2(\mathrm{CH}), 132.5(\mathrm{CH}), 129.5(\mathrm{CH}), 127.8(\mathrm{CH})$, 
$127.2(\mathrm{C}), 124.4(\mathrm{C}), 121.6(\mathrm{CH}), 110.8(\mathrm{CH}), 85.7(\mathrm{C}), 83.2(\mathrm{CH}), 78.9(\mathrm{CH}), 51.5\left(\mathrm{CH}_{3}\right)$, $21.9\left(\mathrm{CH}_{3}\right)$; LRMS (EI) m/z (relative intensity): 269.8 (37); HRMS (EI) Calcd for $\left[\mathrm{C}_{16} \mathrm{H}_{14} \mathrm{O}_{4}\right]$ 270.0887, Found 270.0895. HPLC analysis: ee 94\% (OJ column, 1\% i-PrOH in hexanes, $1 \mathrm{~mL} / \mathrm{min}, \lambda=254 \mathrm{~nm}, \mathrm{t}_{\mathrm{R}}=10.08 \mathrm{~min}$, major; $12.12 \mathrm{~min}$, minor).

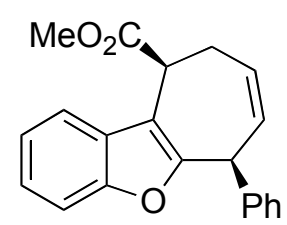

12

(E)-1-(buta-1,3-dienyl)benzene (1.96 g, $14.9 \mathrm{mmol})$ and $\mathrm{Rh}_{2}(\mathrm{R} \text {-DOSP) })_{4}(18.7 \mathrm{mg}, 0.009$ $\mathrm{mmol})$ were dissolved in toluene $(20 \mathrm{~mL})$ and cooled to $-78^{\circ} \mathrm{C}$ in a dry ice/acetone bath. Methyl 2-(benzofuran-3-yl)diazoacetate $8(215 \mathrm{mg}, 0.99 \mathrm{mmol})$ was dissolved in toluene $(10 \mathrm{~mL})$ and added via syringe pump over $1 \mathrm{~h}$. The reaction was stirred for $16 \mathrm{~h}$ while being allowed to warm slowly to room temperature. The solvent was then removed under reduced pressure and the diastereomeric excess (>94\%) was obtained (determined by ${ }^{1} \mathrm{H}$ NMR of crude reaction mixture). The residue was purified by column chromatography $\left(\mathrm{SiO}_{2}\right.$, diethyl ether:pentane $\left.=1: 9\right)$ to obtain 12 as a white solid in $62 \%$ yield (197 mg). mp: $99-101^{\circ} \mathrm{C} ;[\alpha]_{\mathrm{D}}^{20}=104.4^{\circ}$ (c 1.0, $\mathrm{CHCl}_{3}$ ); FTIR (neat): 3026, 2949, 1711, 1603, 1462, 1453, $1263 \mathrm{~cm}^{-1} ;{ }^{1} \mathrm{H}$ NMR $\left(500 \mathrm{MHz}, \mathrm{CDCl}_{3}\right) \delta 3.45(\mathrm{~m}, 2 \mathrm{H}), 3.86(\mathrm{~s}$, 3H), $4.01(\mathrm{~d}, 1 \mathrm{H}, \mathrm{J}=4.5 \mathrm{~Hz}), 5.66(\mathrm{~m}, 1 \mathrm{H}), 5.97(\mathrm{~m}, 1 \mathrm{H}),, 6.04(\mathrm{~d}, 1 \mathrm{H}, \mathrm{J}=4.5 \mathrm{~Hz}), 6.62$ $(\mathrm{m}, 2 \mathrm{H}), 7.00(\mathrm{~m}, 4 \mathrm{H}), 7.18(\mathrm{~d}, 1 \mathrm{H}, J=6.5 \mathrm{~Hz}), 7.84(\mathrm{~d}, 1 \mathrm{H}, \mathrm{J}=8.0 \mathrm{~Hz}) ;{ }^{13} \mathrm{C}$ NMR $(75$ $\left.\mathrm{MHz}, \mathrm{CDCl}_{3}\right) \delta 177.1$ (C), 167.5 (C), 164.9 (C), 149.5 (C), $136.2(\mathrm{C}), 131.9(\mathrm{CH}), 130.0$ (CH), $129.0(\mathrm{CH}), 127.2(\mathrm{CH}), 127.0(\mathrm{CH}), 126.9(\mathrm{CH}), 126.6(\mathrm{CH}), 122.9(\mathrm{CH}), 120.2$ $(\mathrm{CH}), 119.6(\mathrm{C}), 109.9(\mathrm{CH}), 85.9(\mathrm{CH}), 51.6\left(\mathrm{CH}_{3}\right), 46.9(\mathrm{CH}), 44.5(\mathrm{C}), 29.5\left(\mathrm{CH}_{2}\right)$; LRMS (EI) m/z (relative intensity): 318.2 (43); HRMS (EI) Calcd for $\left[\mathrm{C}_{21} \mathrm{H}_{18} \mathrm{O}_{3}\right]$ 318.1250, Found 318.1256. HPLC analysis: ee 97\% (OD-H column, 1\% i-PrOH in hexanes, 0.6 $\mathrm{mL} / \mathrm{min}, \lambda=254 \mathrm{~nm}$, tr = $13.14 \mathrm{~min}$, major; $16.20 \mathrm{~min}$, minor). 


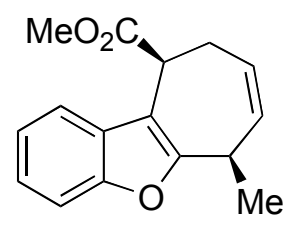

13

(E)-penta-1,3-diene 5 (709 mg, $10.4 \mathrm{mmol})$ and $\mathrm{Rh}_{2}(\mathrm{R} \text {-DOSP })_{4}(26.2 \mathrm{mg}, 0.014 \mathrm{mmol})$ were dissolved in toluene $(20 \mathrm{~mL})$ and cooled to $-78{ }^{\circ} \mathrm{C}$ in a dry ice/acetone bath. Methyl 2-(benzofuran-3-yl)diazoacetate 8 (300 mg, $1.39 \mathrm{mmol})$ was dissolved in toluene (10 $\mathrm{mL}$ ) and added via syringe pump over $1 \mathrm{~h}$. The reaction was stirred for $16 \mathrm{~h}$ while being allowed to warm slowly to room temperature. The solvent was then removed under reduced pressure and the diastereomeric excess (>94\%) was obtained (determined by ${ }^{1} \mathrm{H}$ NMR of crude reaction mixture). The residue was purified by column chromatography $\left(\mathrm{SiO}_{2}\right.$, diethyl ether:pentane $\left.=1: 9\right)$ to obtain 13 as a white solid in $62 \%$ yield $(222 \mathrm{mg})$. $\mathrm{mp}: 60-61^{\circ} \mathrm{C} ;[\alpha]_{D}^{20}=-105.6^{\circ}\left(c 1.0, \mathrm{CHCl}_{3}\right) ; \mathrm{FTIR}$ (neat): 2969, 1709, 1601, 1462, 1260, $1217 \mathrm{~cm}^{-1} ;{ }^{1} \mathrm{H}$ NMR (500 MHz, $\left.\mathrm{CDCl}_{3}\right) \delta 0.86(\mathrm{~d}, 3 \mathrm{H}, \mathrm{J}=6.5 \mathrm{~Hz}), 2.81(\mathrm{~d}, 1 \mathrm{H}, \mathrm{J}=4.0$ $\mathrm{Hz}), 3.29(\mathrm{~d}, 1 \mathrm{H}, \mathrm{J}=4.5 \mathrm{~Hz}), 3.87(\mathrm{~s}, 3 \mathrm{H}), 5.62(\mathrm{~m}, 2 \mathrm{H}),, 5.90(\mathrm{~d}, 1 \mathrm{H}, \mathrm{J}=4.0 \mathrm{~Hz}), 6.92$ $(\mathrm{m}, 2 \mathrm{H}), 7.30(\mathrm{~m}, 1 \mathrm{H}), 8.16(\mathrm{~d}, 1 \mathrm{H}, J=8.0 \mathrm{~Hz}) ;{ }^{13} \mathrm{C} \quad \mathrm{NMR}\left(75 \mathrm{MHz}, \mathrm{CDCl}_{3}\right) \delta 167.8(\mathrm{C})$, $165.4(\mathrm{C}), 148.7(\mathrm{C}), 132.3(\mathrm{CH}), 126.8(\mathrm{CH}), 125.0(\mathrm{CH}), 123.4(\mathrm{C}), 120.7(\mathrm{CH}), 120.6$ $(\mathrm{CH}), 110.2(\mathrm{CH}), 86.6(\mathrm{CH}), 51.7\left(\mathrm{CH}_{3}\right), 36.4(\mathrm{CH}), 29.7\left(\mathrm{CH}_{2}\right), 13.7\left(\mathrm{CH}_{3}\right)$; LRMS (EI) m/z (relative intensity): 256.9 (21); HRMS (El) Calcd for $\left[\mathrm{C}_{16} \mathrm{H}_{17} \mathrm{O}_{3}\right]$ 257.1172, Found 257.1128; Anal. Calcd for $\mathrm{C}_{16} \mathrm{H}_{17} \mathrm{O}_{3}$ : C, 74.98; $\mathrm{H}, 6.29 ; \mathrm{O}, 18.83$. Found: $\mathrm{C}, 74.94 ; \mathrm{H}$, 6.27; O, 18.59. HPLC analysis: ee $>98 \%$ (OJ column, $1 \% \mathrm{i}-\mathrm{PrOH}$ in hexanes, 0.8 $\mathrm{mL} / \mathrm{min}, \lambda=254 \mathrm{~nm}, \mathrm{t}_{\mathrm{R}}=12.64 \mathrm{~min}$, major; $15.45 \mathrm{~min}$, minor)

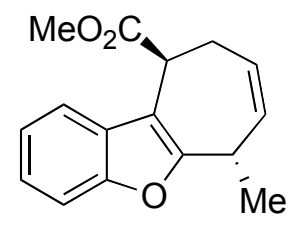

14 
(Z)-penta-1,3-diene $(645 \mathrm{mg}, 13.8 \mathrm{mmol})$ and $\mathrm{Rh}_{2}(\mathrm{R} \text {-DOSP })_{4}(17.4 \mathrm{mg}, 0.0093 \mathrm{mmol})$ were dissolved in toluene $(9 \mathrm{~mL})$ and cooled to $-78^{\circ} \mathrm{C}$ in a dry ice/acetone bath. Methyl 2-(benzofuran-3-yl)diazoacetate $8(200 \mathrm{mg}, 0.931 \mathrm{mmol})$ was dissolved in toluene (6 $\mathrm{mL}$ ) and added via syringe pump over $1 \mathrm{~h}$. The reaction was stirred for $16 \mathrm{~h}$ while being allowed to warm slowly to room temperature. The solvent was then removed under reduced pressure and the diastereomeric excess 2.7: 1 was obtained (determined by ${ }^{1} \mathrm{H}$ NMR of crude reaction mixture). The residue was purified by column chromatography $\left(\mathrm{SiO}_{2}\right.$, diethyl ether:pentane $\left.=1: 19\right)$ to obtain cyclopropane as a white solid in $43 \%$ yield (101 mg). Cyclopropane was dissolved in xylenes $(8 \mathrm{~mL})$ and heated to $140^{\circ} \mathrm{C}$ for $4 \mathrm{~h}$, then cooled to room temperature and concentrated to get 14 a colorless oil $(101 \mathrm{mg})$. $[\alpha]_{\mathrm{D}}{ }^{20}=-31.3^{\circ}$ (c $\left.0.25, \mathrm{CHCl}_{3}\right) ; \mathrm{FTIR}$ (neat): 2951, 1711, 1601, 1462, $1265 \mathrm{~cm}^{-1} ;{ }^{1} \mathrm{H}$ NMR $\left(500 \mathrm{MHz}, \mathrm{CDCl}_{3}\right) \delta 1.30(\mathrm{~d}, 3 \mathrm{H}, \mathrm{J}=7.0 \mathrm{~Hz}), 2.42(\mathrm{~m}, 1 \mathrm{H}), 3.19(\mathrm{~m}, 2 \mathrm{H}), 3.87(\mathrm{~s}, 3 \mathrm{H})$, 5.37(m, 1H, ), $5.49(\mathrm{~d}, 1 \mathrm{H}, \mathrm{J}=11.0 \mathrm{~Hz}), 5.71(\mathrm{~m}, 1 \mathrm{H}), 6.93(\mathrm{~m}, 2 \mathrm{H}), 7.31(\mathrm{t}, 1 \mathrm{H}), 8.22(\mathrm{~d}$, $1 \mathrm{H}, \mathrm{J}=8.0 \mathrm{~Hz}) ;{ }^{13} \mathrm{C} \operatorname{NMR}\left(75 \mathrm{MHz}, \mathrm{CDCl}_{3}\right) \delta 167.7$ (C), 164.5 (C), 149.9 (C), 133.1 $(\mathrm{CH}), 132.3(\mathrm{CH}), 127.5(\mathrm{CH}), 124.9(\mathrm{CH}), 122.5(\mathrm{C}), 122.0(\mathrm{C}), 120.8(\mathrm{CH}), 110.7(\mathrm{CH})$, $88.8(\mathrm{CH}), 51.7\left(\mathrm{CH}_{3}\right), 36.5(\mathrm{CH}), 28.7\left(\mathrm{CH}_{2}\right), 19.6\left(\mathrm{CH}_{3}\right)$; LRMS (EI) m/z (relative intensity): 257.0 (100); HRMS (EI) Calcd for $\left[\mathrm{C}_{16} \mathrm{H}_{17} \mathrm{O}_{3}\right]$ 257.1172, Found 257.1173. HPLC analysis: $93 \%$ ee (AS-H column, 1\% i-PrOH in hexanes, $0.8 \mathrm{~mL} / \mathrm{min}, \lambda=254 \mathrm{~nm}$, $\operatorname{tr}=7.27 \mathrm{~min}, \operatorname{minor} ; 9.01 \mathrm{~min}, \operatorname{minor})$;

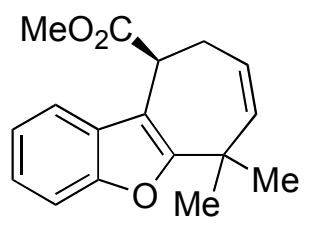

15

4-methylpenta-1,3-diene (569 mg, $6.94 \mathrm{mmol})$ and $\mathrm{Rh}_{2}(\mathrm{R} \text {-DOSP })_{4}(8.73 \mathrm{mg}, 0.0046$ $\mathrm{mmol})$ were dissolved in toluene $(7 \mathrm{~mL})$ and cooled to $-78^{\circ} \mathrm{C}$ in a dry ice/acetone bath. 
Methyl 2-(benzofuran-3-yl)diazoacetate 8 (100 mg, $0.463 \mathrm{mmol})$ was dissolved in toluene $(3 \mathrm{~mL})$ and added via syringe pump over $1 \mathrm{~h}$. The reaction was stirred for $16 \mathrm{~h}$ while being allowed to warm slowly to room temperature. The reaction was heated to reflux $\left(110^{\circ}\right)$ for $20 \mathrm{~h}$, then cooled to room temperature. The solvent was then removed under reduced pressure and the diastereomeric excess (>94\%) was obtained (determined by ${ }^{1} \mathrm{H}$ NMR of crude reaction mixture). The residue was purified by column chromatography $\left(\mathrm{SiO}_{2}\right.$, diethyl ether:pentane $\left.=1: 19\right)$ to obtain 15 as a colorless oil in $82 \%$ yield. FTIR (neat): 2962, 1712, 1602, 1463, 1434, 1262, 1198, $1150 \mathrm{~cm}^{-1} ;{ }^{1} \mathrm{H}$ NMR $\left(500 \mathrm{MHz}, \mathrm{CDCl}_{3}\right) \delta 0.79(\mathrm{~s}, 3 \mathrm{H}), 1.27(\mathrm{~s}, 3 \mathrm{H}), 3.18(\mathrm{~m}, 2 \mathrm{H}), 3.84(\mathrm{~s}, 3 \mathrm{H}), 5.27(\mathrm{dd}, 1 \mathrm{H}, J$ $=11.75 \mathrm{~Hz}, 2.0 \mathrm{~Hz}), 5.56(\mathrm{~m}, 2 \mathrm{H}), 6.90(\mathrm{~m}, 1 \mathrm{H}) 7.30(\mathrm{t}, 1 \mathrm{H}), 8.14(\mathrm{~d}, 1 \mathrm{H}, J=8.0 \mathrm{~Hz}) ;{ }^{13} \mathrm{C}$ NMR (75 MHz, $\left.\mathrm{CDCl}_{3}\right) \delta 167.6(\mathrm{C}), 165.2$ (C), 165.4 (C), $149.1(\mathrm{C}), 138.4(\mathrm{CH}), 132.2$ $(\mathrm{CH}), 126.8(\mathrm{CH}), 123.2(\mathrm{C}), 122.5(\mathrm{CH}), 120.6(\mathrm{CH}), 121.9(\mathrm{C}), 120.6(\mathrm{CH}), 110.1(\mathrm{CH})$ $90.6(\mathrm{CH}), 51.6\left(\mathrm{CH}_{3}\right), 38.9(\mathrm{C}), 28.8\left(\mathrm{CH}_{2}\right), 28.2\left(\mathrm{CH}_{3}\right), 21.4\left(\mathrm{CH}_{3}\right)$; LRMS (EI) m/z (relative intensity): 270.2 (98); HRMS (El) Calcd for $\left[\mathrm{C}_{17} \mathrm{H}_{18} \mathrm{O}_{3}\right]$ 270.1250, Found 270.1244. HPLC analysis: $91 \%$ ee (AS-H column, $1 \%$ i-PrOH in hexanes, $0.8 \mathrm{~mL} / \mathrm{min}, \lambda$ $=254 \mathrm{~nm}, \mathrm{t}_{\mathrm{R}}=6.31 \mathrm{~min}$, major; $7.42 \mathrm{~min}$, minor $)$

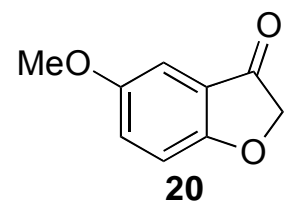

The compound $\mathbf{2 0}$ was synthesized via a modified literature procedure. To an ice cold solution of boron trichloride (1M in methylene chloride, $90 \mathrm{~mL}$ ) was added a solution of 4-methoxyphenol 19 (9.0 g, $72.5 \mathrm{mmol})$ in 1,2-dichloroethane (36 mL) dropwise over $1 \mathrm{~h}$. To the resulting mixture was added chloroacetonitrile $(5.51 \mathrm{~mL}, 87.0 \mathrm{mmol})$ dropwise over $10 \mathrm{~min}$ and solid aluminum chloride $(4.84 \mathrm{~g}, 36.3 \mathrm{mmol})$ was added portionwise over $30 \mathrm{~min}$. The reaction was stirred for $2.5 \mathrm{~h}$, then poured into a mixture of ice and $2 \mathrm{~N}$ 
$\mathrm{HCl}(90 \mathrm{~mL} / 100 \mathrm{~mL})$. The aqueous layer was extracted into methylene chloride $(2 \times 75$ $\mathrm{mL}$ ), washed with brine and dried over $\mathrm{MgSO}_{4}$. The reaction was filtered and concentrated to get the crude a-chloro-2-hydroxy-5-methoxyacetophenone. This material was dissolved in methanol $(72 \mathrm{~mL})$ and treated with sodium acetate $(19.8 \mathrm{~g}, 219 \mathrm{mmol})$, then heated to reflux $\left(65^{\circ} \mathrm{C}\right)$. The reaction was stirred for $1.5 \mathrm{~h}$, cooled to room temperature and poured into $\mathrm{H}_{2} \mathrm{O}(100 \mathrm{~mL})$. The reaction was extracted into diethyl ether (3 $\times 60 \mathrm{~mL}$ ), washed with brine and dried over $\mathrm{MgSO}_{4}$. The reaction was filtered, concentrated and the residue was purified by recrystallization in petroleum ether to obtain 20 as a red solid in $68 \%$ yield $(8.10 \mathrm{~g}) .{ }^{1} \mathrm{H}$ NMR $\left(500 \mathrm{MHz}, \mathrm{CDCl}_{3}\right) \delta 3.82(\mathrm{~s}, 3 \mathrm{H})$, $4.63(\mathrm{~s}, 2 \mathrm{H}), 7.05(\mathrm{~d}, 2 \mathrm{H}, \mathrm{J}=2.0 \mathrm{~Hz}), 7.28(\mathrm{dd}, 1 \mathrm{H}, \mathrm{J}=8.0 \mathrm{~Hz}, 2.0 \mathrm{~Hz})$. Matches previously reported data.

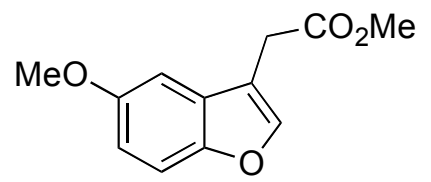

21

Compound 21 was prepared via a literature procedure. 5-methoxybenzofuran-3(2H)-one $20(0.98 \mathrm{~g}, 5.97 \mathrm{mmol})$, and methyl (triphenyl phosphoranylidene)acetate $(3.0 \mathrm{~g}, 8.95$ $\mathrm{mmol})$ were dissolved in xylenes $(20 \mathrm{~mL})$ and heated to reflux $\left(140^{\circ} \mathrm{C}\right)$. The reaction was stirred at reflux for $60 \mathrm{~h}$, cooled to room temperature, and filtered through a plug of silica. The filtrate was concentrated and the residue was purified by column chromatography $\left(\mathrm{SiO}_{2}\right.$, diethyl ether:pentane $\left.=1: 9\right)$ to obtain 21 as a yellow oil in $61 \%$ yield $(0.79 \mathrm{~g}) .{ }^{1} \mathrm{H}$ NMR (500 MHz, $\left.\mathrm{CDCl}_{3}\right) \delta 3.71(\mathrm{~s}, 2 \mathrm{H}), 3.76(\mathrm{~s}, 3 \mathrm{H}), 3.88(\mathrm{~s}, 3 \mathrm{H}), 6.93$ (dd, 1H, J = 2.0 $\mathrm{Hz}, 9.0 \mathrm{~Hz}), 7.02(\mathrm{~d}, 1 \mathrm{H}, \mathrm{J}=2.0 \mathrm{~Hz}$ ), $7.38(\mathrm{~d}, 1 \mathrm{H}, \mathrm{J}=9.0 \mathrm{~Hz}), 7.62(\mathrm{~s}, 1 \mathrm{H})$. Matches previously reported data. 


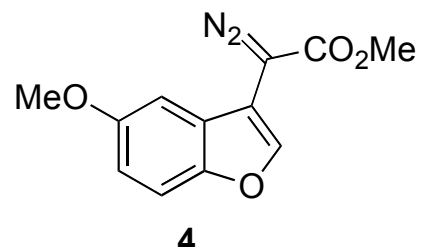

Methyl 2-(5-methoxybenzofuran-3-yl)acetate 21 (0.79 g, $3.6 \mathrm{mmol})$, and paraacetamidobenzenesulfonyl azide ( $\mathrm{p}-\mathrm{ABSA})(1.09 \mathrm{~g}, 4.53 \mathrm{mmol})$ were dissolved in acetonitrile $(15 \mathrm{~mL})$ and cooled to $0{ }^{\circ} \mathrm{C} .1,8$-Diazobicyclo[5.4.0]undec-7-ene (DBU) (1.09 $\mathrm{g}, 7.2 \mathrm{mmol}$ ) was added in one portion and the reaction was stirred at $0{ }^{\circ} \mathrm{C}$ for $1 \mathrm{~h}$, then 3 additional $\mathrm{h}$ at room temperature. The reaction was poured into saturated ammonium chloride and extracted into diethyl ether. The combined organic layers were dried over $\mathrm{MgSO}_{4}$, filtered and concentrated to obtain the crude product. The crude material was purified by column chromatography $\left(\mathrm{SiO}_{2}\right.$, petroleum ether:diethyl ether $\left.=9: 1\right)$ to obtain 4 as an orange solid in $81 \%$ yield $(0.72 \mathrm{~g})$. $\mathrm{mp}=80-81^{\circ} \mathrm{C}$; FTIR (neat): 2092, 1697, 1479, 1434, 1256, $1213 \mathrm{~cm}^{-1} ;{ }^{1} \mathrm{H}$ NMR $\left(500 \mathrm{MHz}, \mathrm{CDCl}_{3}\right) \delta 3.84(\mathrm{~s}, 3 \mathrm{H}), 3.90(\mathrm{~s}, 3 \mathrm{H})$, $6.94(\mathrm{~m}, 2 \mathrm{H}), 7.41(\mathrm{~d}, 1 \mathrm{H}, \mathrm{J}=8.5 \mathrm{~Hz}), 7.93(\mathrm{~s}, 1 \mathrm{H}) ;{ }^{13} \mathrm{C}$ NMR $\left(75 \mathrm{MHz}, \mathrm{CDCl}_{3}\right) \delta 156.1$, 149.9, 142.8, 125.1, 113.5, 112.4, 103.7, 101.5, 55.9, 52.4; Anal. Calcd for $\mathrm{C}_{12} \mathrm{H}_{10} \mathrm{~N}_{2} \mathrm{O}_{4}$ : C, 58.54; H, 4.09; N, 11.38. Found C, 58.69; H, 4.11; N, 11.28.

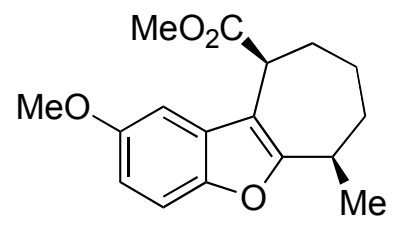

22

(E)-penta-1,3-diene $5(2.21 \mathrm{~g}, 32.5 \mathrm{mmol})$ and $\mathrm{Rh}_{2}(\mathrm{R}-\mathrm{DOSP})_{4}(30.5 \mathrm{mg}, 0.016 \mathrm{mmol})$ were dissolved in toluene $(25 \mathrm{~mL})$ and cooled to $-78{ }^{\circ} \mathrm{C}$ in a dry ice/acetone bath. Methyl 2-(5-methoxybenzofuran-3-yl)acetate $4(400 \mathrm{mg}, 1.62 \mathrm{mmol})$ was dissolved in toluene $(15 \mathrm{~mL})$ and added via syringe pump over $1 \mathrm{~h}$. The reaction was stirred for $4 \mathrm{~h}$ while being allowed to warm slowly to room temperature. The reaction was then heated to 
$80^{\circ} \mathrm{C}$ for $30 \mathrm{~min}$, cooled to room temperature and concentrated. A solution of the crude product and $5 \% \mathrm{Pd} / \mathrm{C}(400 \mathrm{mg})$ in ethanol $(30 \mathrm{~mL})$ was shaken at $42 \mathrm{psi} \mathrm{H}_{2}$ for $4 \mathrm{~h}$. The crude mixture was filtered through celite, washed with diethyl ether and the solvent was removed under reduced pressure and the diastereomeric excess (>94\%) was obtained (determined by ${ }^{1} \mathrm{H}$ NMR of crude reaction mixture). The residue was purified by column chromatography $\left(\mathrm{SiO}_{2}\right.$, diethyl ether:pentane $\left.=1: 9\right)$ to obtain 22 as a colorless oil in $57 \%$ yield $(268 \mathrm{mg}) .[\alpha]_{\mathrm{D}}^{20}=24.5^{\circ}$ (c $\left.0.95, \mathrm{CHCl}_{3}\right)$; FTIR (neat): 2931 , 1736, 1477, $1208 \mathrm{~cm}^{-1} ;{ }^{1} \mathrm{H}$ NMR (500 MHz, $\left.\mathrm{CDCl}_{3}\right) \delta 1.35(\mathrm{~d}, 3 \mathrm{H}, \mathrm{J}=7.5 \mathrm{~Hz}), 1.85(\mathrm{~m}$, 4H), $2.10(\mathrm{~m}, 1 \mathrm{H}), 2.48(\mathrm{~m}, 1 \mathrm{H}), 3.24(\mathrm{~m}, 1 \mathrm{H}), 3.70(\mathrm{~s}, 3 \mathrm{H}), 3.85(\mathrm{~s}, 3 \mathrm{H}), 3.96(\mathrm{t}, 1 \mathrm{H})$, $6.83(\mathrm{~m}, 2 \mathrm{H}), 7.28(\mathrm{~m}, 1 \mathrm{H}) ;{ }^{13} \mathrm{C} \quad \mathrm{NMR}\left(75 \mathrm{MHz}, \mathrm{CDCl}_{3}\right) \delta 173.9,161.6,155.8,148.2$, $130.7,112.1,111.5,111.0,101.7,56.00,51.97,39.62,33.49,33.21,30.90,21.38$, 19.07; LRMS (EI) m/z (relative intensity): 288.2 (68); HRMS (EI) Calcd for $\mathrm{C}_{17} \mathrm{H}_{20} \mathrm{O}_{4}$ : 288.1356, Found 288.1358; HPLC analysis: ee $>97 \%$ (OD-H column, $0.8 \%$ i-PrOH in hexanes, $1 \mathrm{~mL} / \mathrm{min}, \lambda=254 \mathrm{~nm}, \mathrm{t}_{\mathrm{R}}=7.89 \mathrm{~min}$, major; $10.34 \mathrm{~min}$, minor);

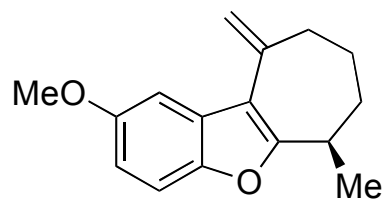

23

A solution of compound $22(0.260 \mathrm{~g}, 0.902 \mathrm{mmol})$ in THF $(10 \mathrm{~mL})$ was cooled to $-78{ }^{\circ} \mathrm{C}$ and treated with $\mathrm{LiAlH}_{4},(2.4 \mathrm{M}$ in THF, $0.47 \mathrm{~mL}, 1.13 \mathrm{mmol})$. After being stirred at $-78^{\circ} \mathrm{C}$ for 15 minutes, the solution was warmed to $0^{\circ} \mathrm{C}$ and stirred for $1.5 \mathrm{~h}$. The reaction mixture was then quenched with sodium sulfate decahydrate. The material was then filtered through celite, washed with diethyl ether, and the filtrate was concentrated under reduced pressure to obtain crude alcohol. A solution of the crude alcohol was dissolved in dichloromethane $(10 \mathrm{~mL})$ and treated with toluenesulfonyl chloride $(0.258 \mathrm{~g}, 1.41$ mmol) and triethylamine $(0.365 \mathrm{~g}, 3.61 \mathrm{mmol})$. The reaction was stirred for $4 \mathrm{~h}$, then 
poured into $\mathrm{H}_{2} \mathrm{O}(10 \mathrm{~mL})$, and extracted into dichloromethane. The combined organics were washed with $\mathrm{H}_{2} \mathrm{O}$ and brine, dried $\left(\mathrm{MgSO}_{4}\right)$, and concentrated to obtain the crude tosylate. The crude tosylate was dissolved in DMF $(3 \mathrm{~mL})$, treated with DBU $(0.411 \mathrm{~g}$, $2.71 \mathrm{mmol}$ ) and heated to $130^{\circ} \mathrm{C}$ for $2 \mathrm{~h}$. The reaction was cooled to room temperature and purified by column chromatography $\left(\mathrm{SiO}_{2}\right.$, pentane) to obtain 23 as a colorless oil in $80 \%$ yield $(176 \mathrm{mg}) \cdot[\alpha]^{20}=20.7^{\circ}$ (c $0.10, \mathrm{CHCl}_{3}$ ); FTIR (neat): 2930, 1631, 1475, 1268, $1204 \mathrm{~cm}^{-1} ;{ }^{1} \mathrm{H}$ NMR $\left(500 \mathrm{MHz}, \mathrm{CDCl}_{3}\right) \delta 1.35(\mathrm{~d}, 3 \mathrm{H}, \mathrm{J}=7.0 \mathrm{~Hz}), 1.75(\mathrm{~m}, 1 \mathrm{H}), 1.84(\mathrm{~m}$, 1H), $1.97(\mathrm{~m}, 2 \mathrm{H}), 2.10(\mathrm{~m}, 1 \mathrm{H}), 2.53(\mathrm{~m}, 2 \mathrm{H}), 3.16(\mathrm{~m}, 1 \mathrm{H}), 3.84(\mathrm{~s}, 3 \mathrm{H}), 5.23(\mathrm{~s}, 1 \mathrm{H})$, $5.29(\mathrm{~d}, 1 \mathrm{H}, \mathrm{J}=1.5 \mathrm{~Hz}), 6.82(\mathrm{dd}, 1 \mathrm{H}, \mathrm{J}=9.0 \mathrm{~Hz}, 2.5 \mathrm{~Hz}), 7.28(\mathrm{~d}, 1 \mathrm{H}, \mathrm{J}=8.5 \mathrm{~Hz}) ;{ }^{13} \mathrm{C}$ NMR (75 MHz, $\left.\mathrm{CDCl}_{3}\right) \delta 160.6(\mathrm{C}), 155.9(\mathrm{C}), 148.7$ (C), 128.9 (C), 116.7 (C), 113.0 $\left(\mathrm{CH}_{2}\right), 111.6(\mathrm{CH}), 111.1(\mathrm{CH}), 110.8(\mathrm{C}), 103.2(\mathrm{CH}), 56.00\left(\mathrm{CH}_{3}\right), 38.39\left(\mathrm{CH}_{2}\right), 34.07$ (CH), $33.44\left(\mathrm{CH}_{2}\right), 25.79\left(\mathrm{CH}_{2}\right), 18.96\left(\mathrm{CH}_{3}\right)$; LRMS (EI) m/z (relative intensity): 242.1 (90); HRMS (EI) Calcd for $\mathrm{C}_{16} \mathrm{H}_{18} \mathrm{O}_{2}: 242.1301$, Found: 242.1298.

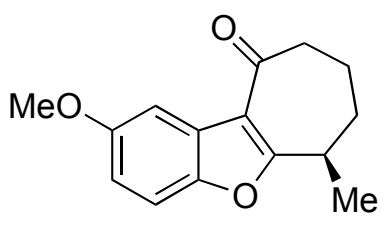

2

A solution of compound $23(68.0 \mathrm{mg}, 0.28 \mathrm{mmol})$, and $\mathrm{RuCl}_{3}$ • $\left(\mathrm{H}_{2} \mathrm{O}\right)$ (2.03 mg, $\left.0.0098 \mathrm{mmol}\right)$ were dissolved in acetonitrile $(3 \mathrm{~mL})$ and $\mathrm{H}_{2} \mathrm{O}(2 \mathrm{~mL})$ and stirred for 5 minutes. A mixture of Oxone $(432 \mathrm{mg}, 0.701 \mathrm{mmol})$ and $\mathrm{NaHCO}_{3}(183 \mathrm{mg}$, $2.18 \mathrm{mmol}$ ) was added portionwise over $10 \mathrm{~min}$, and the reaction was stirred for $16 \mathrm{~h}$. The reaction was poured into a solution of sat. $\mathrm{Na}_{2} \mathrm{~S}_{2} \mathrm{O}_{3}(10 \mathrm{~mL})$, and extracted into $\mathrm{CH}_{2} \mathrm{Cl}_{2}(3 \times 8 \mathrm{~mL})$. The combined organics were washed with $\mathrm{H}_{2} \mathrm{O}$ and brine, dried $\left(\mathrm{MgSO}_{4}\right)$, and concentrated to obtain the crude product. The crude product was purified by column chromatography $\left(\mathrm{SiO}_{2}\right.$, ethyl acetate:hexanes $\left.1: 4\right)$ to obtain 2 as a colorless oil in $73 \%$ yield $(49.9 \mathrm{mg}) .[\alpha]^{20}{ }_{\mathrm{D}}=16.4^{\circ}\left(\mathrm{c} \quad 0.085, \mathrm{CHCl}_{3}\right) ;{ }^{1} \mathrm{H} \mathrm{NMR}\left(500 \mathrm{MHz}, \mathrm{CDCl}_{3}\right) \delta$ 
$1.47(\mathrm{~d}, 3 \mathrm{H}, \mathrm{J}=7.0 \mathrm{~Hz}), 1.79(\mathrm{~m}, 1 \mathrm{H}), 1.89(\mathrm{~m}, 1 \mathrm{H}), 2.03(\mathrm{~m}, 1 \mathrm{H}), 2.21(\mathrm{~m}, 1 \mathrm{H}), 2.81(\mathrm{~m}$, $10 \mathrm{H}), 3.34(\mathrm{~m}, 1 \mathrm{H}), 3.88(\mathrm{~s}, 3 \mathrm{H}), 6.89(\mathrm{dd}, 1 \mathrm{H}, \mathrm{J}=8.75 \mathrm{~Hz}, 2.0 \mathrm{~Hz}), 7.29(\mathrm{~d}, 1 \mathrm{H} \mathrm{J}=9.0$ $\mathrm{Hz}$ ), $7.77(\mathrm{~d}, 1 \mathrm{H} \mathrm{J}=3.0 \mathrm{~Hz})$; HPLC analysis: ee 95\% (OD column, 1\% i-PrOH in hexanes, $2 \mathrm{~mL} / \mathrm{min}, \lambda=254 \mathrm{~nm}, \mathrm{t}_{\mathrm{R}}=6.36$, major; 7.71, minor) Matches previously reported data. 
Jolson-7-32-022807-benzof urantiazo

Polue seguence

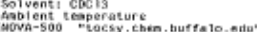

Relax. Helay 2.000 sec
Pulse 34.6 tegreks

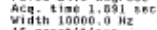

16 regot tilions
OKSERVE

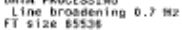

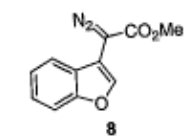

Tatal tae 1 ain, 18 sec

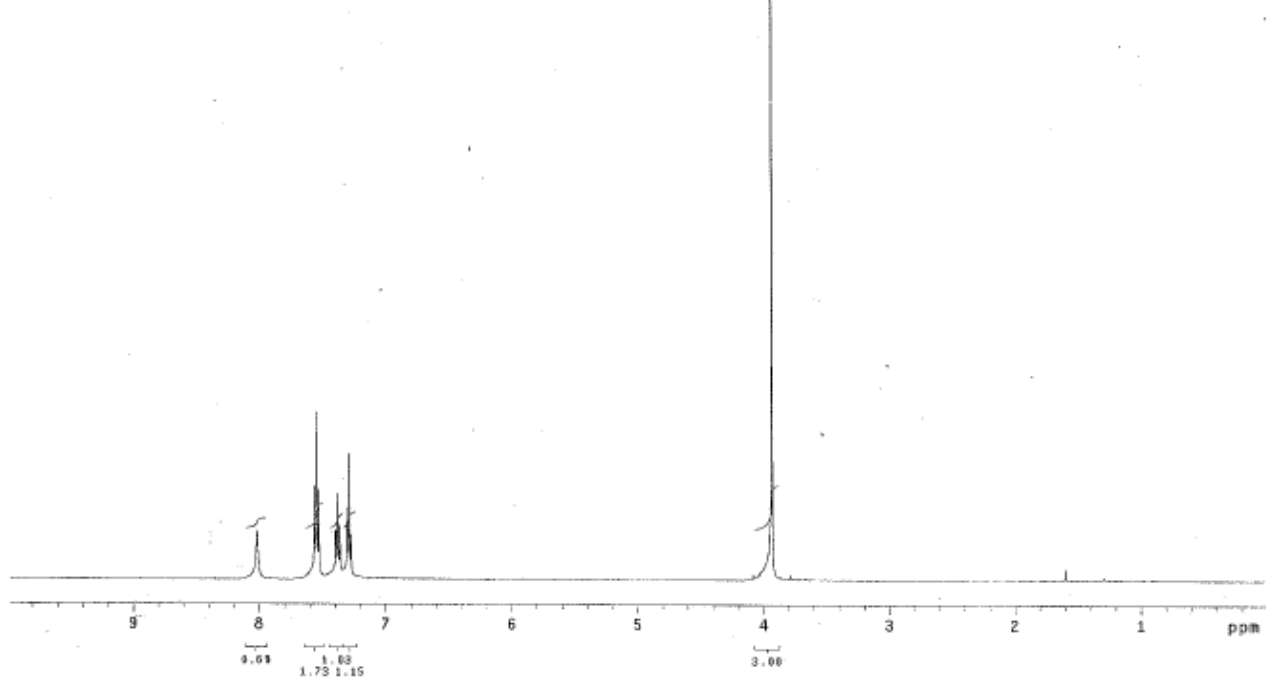

67-benzof urast tazocis 13

Pulse segvencol sazol

Solvent: $\mathrm{CsCl}^{2}$ s.

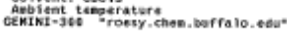

Relax. delay 5.000
Putse soc

vidin $18761: 7 \mathrm{~Hz}$

OSESRVE C13, 75.4536635 MH

Power $1023 \mathrm{~dB}$
cont

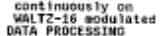

Totâ

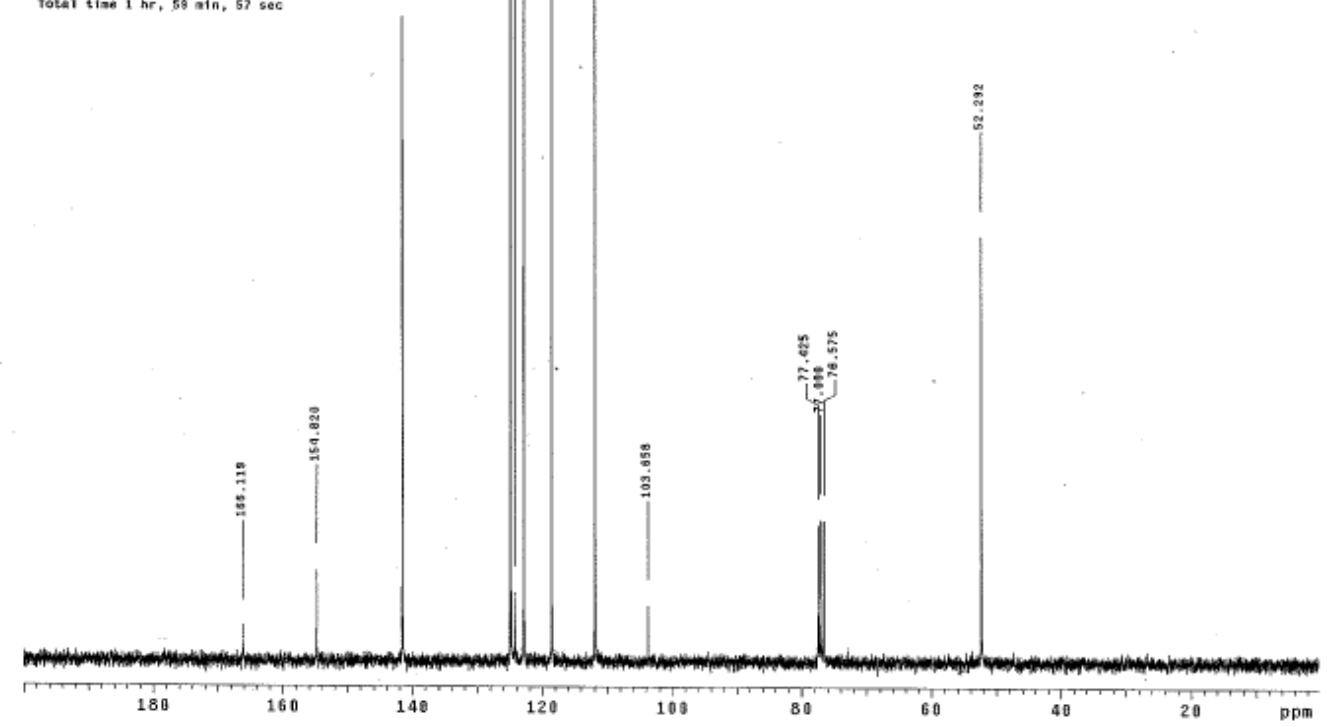

S-15 

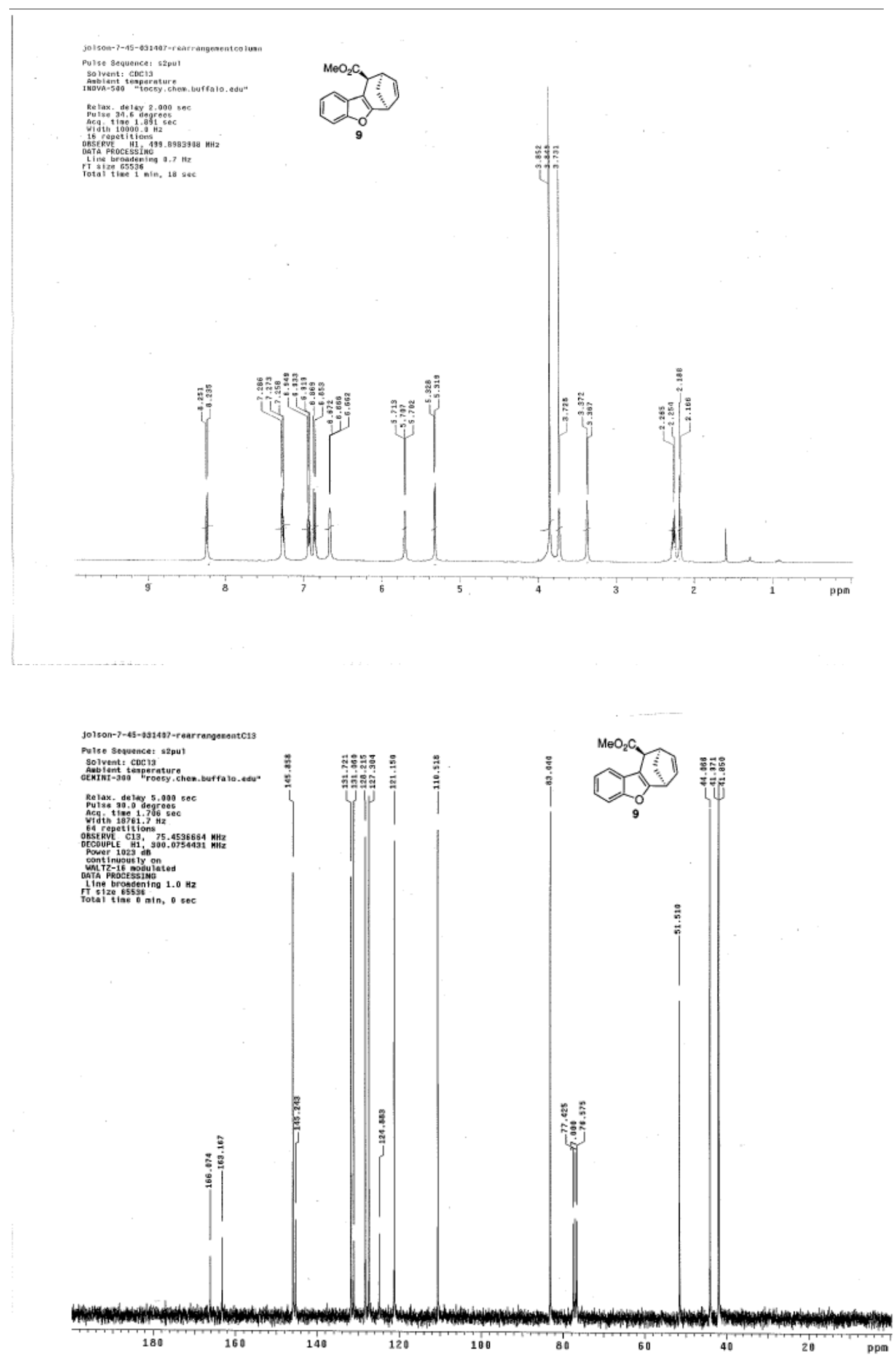
folcon-7-61-040507-furanco tuan

Pulse setuence: s2pu

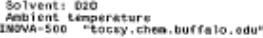

Relax. delay 2,000 tee
Pulse 25.0 degreos

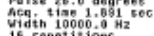

16 repetitions
OESERY

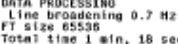

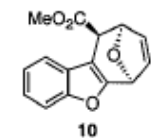

10

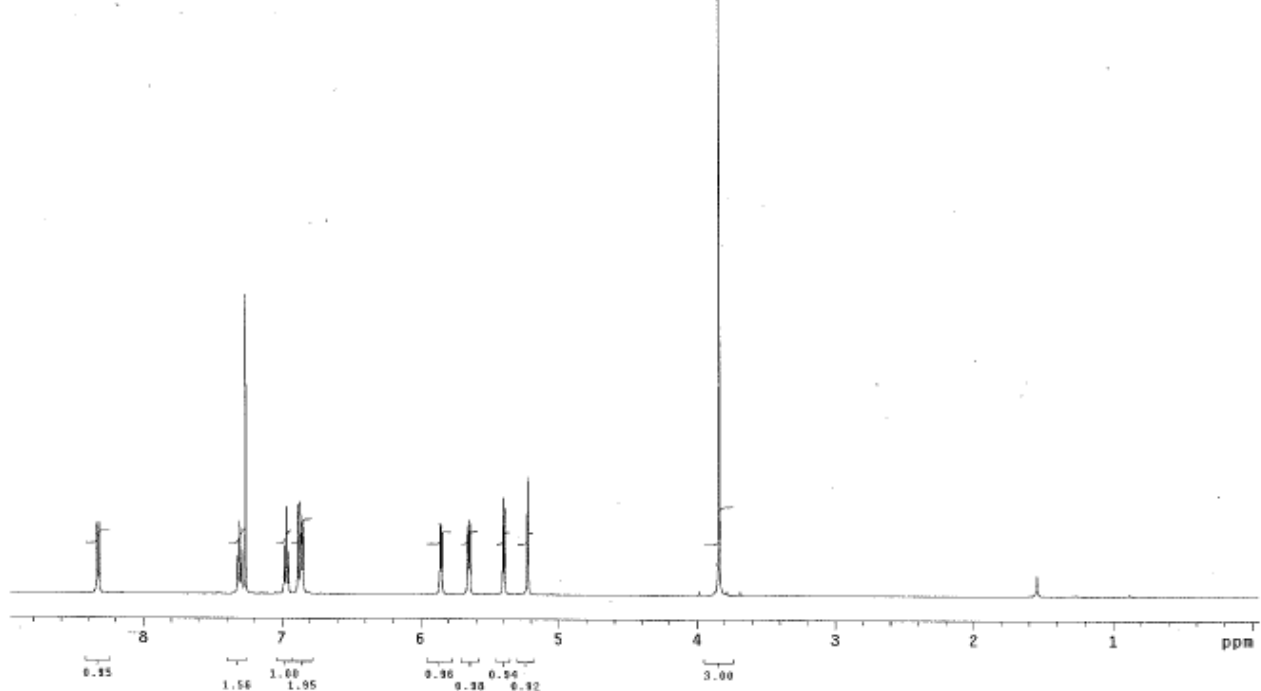

Pulse saquencel e2pu
Solvent! cocis

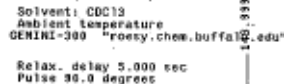

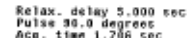

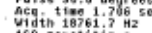

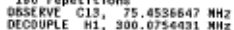

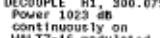

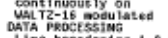

fine bragenting $1.0 \mathrm{Az}$

Total tias $1 \mathrm{hr}, 59$ ain, 57 see
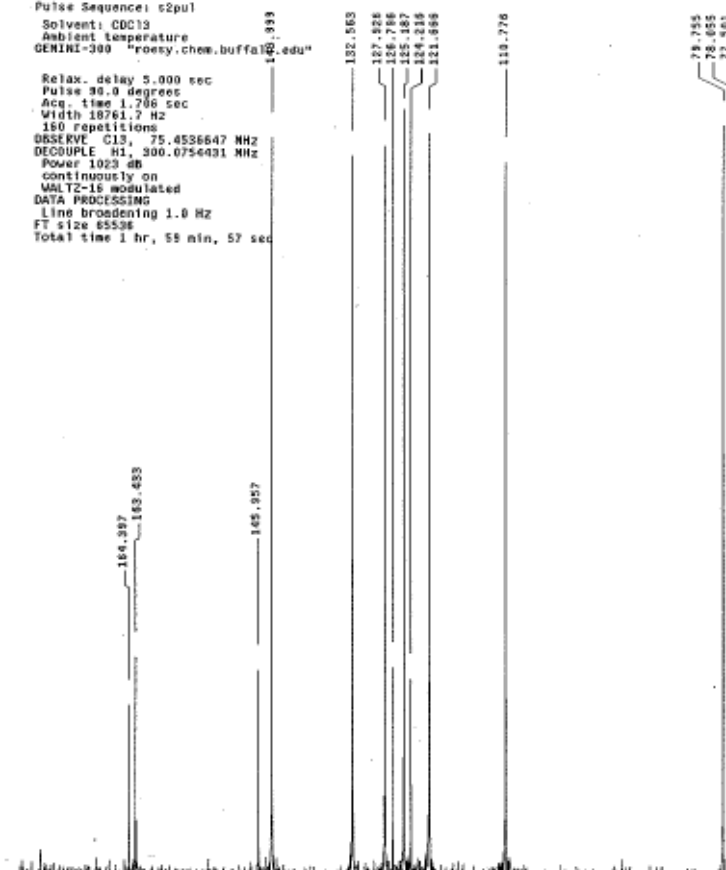

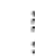

$\ddot{1}$

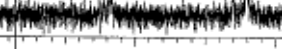

20:

iiv.

160

140

120

100

mit

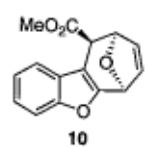

就解

ב.

获 

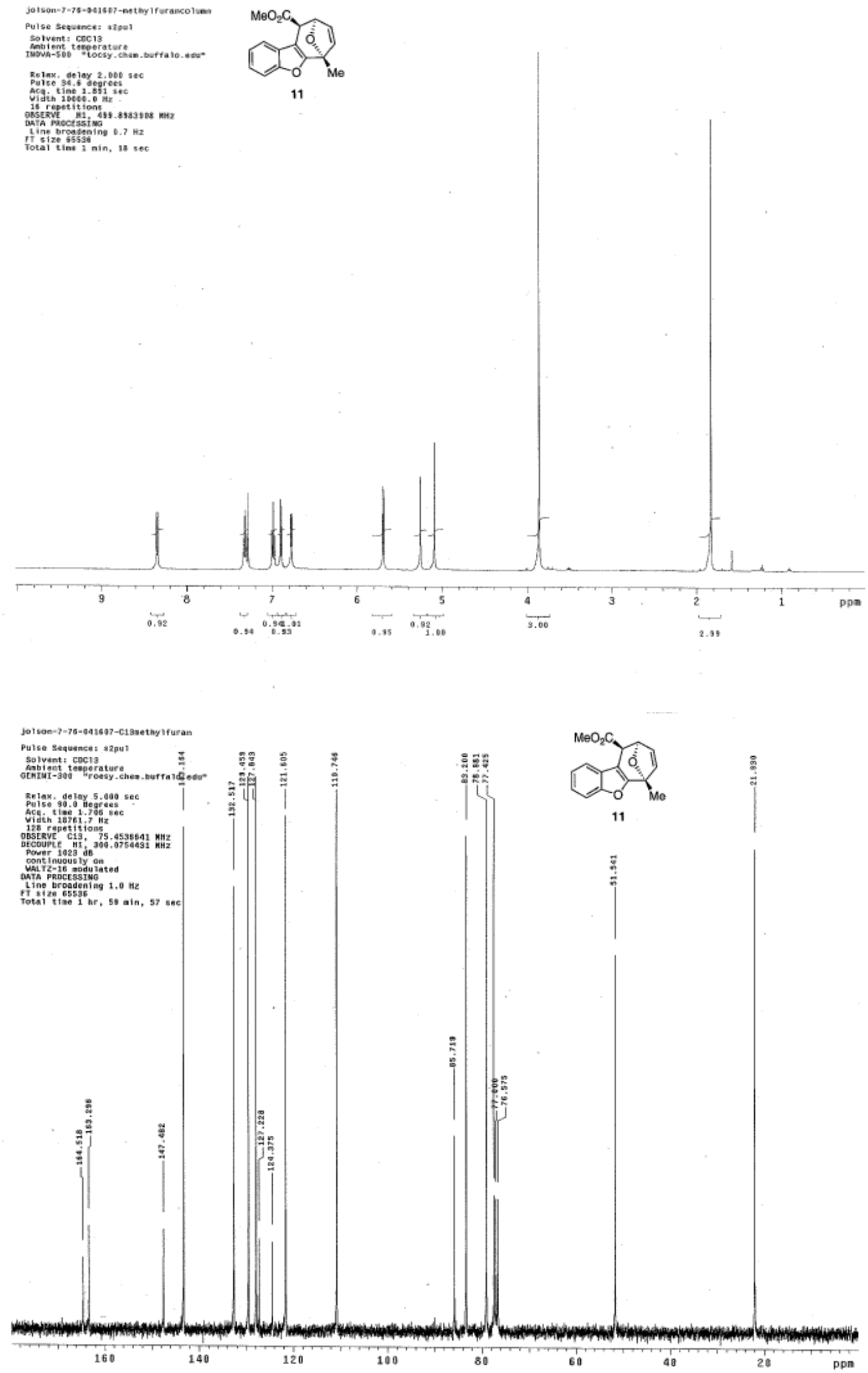
Jo1501-7-43-931267-rect

Palise sequences savel

Solvent cocis

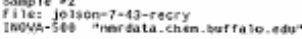

Relax. de lay $7,0 \mathrm{se}$ sec

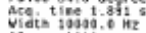

esseravetitions

dif processisic a $\mathrm{kz}$

IT Size 65536 ing $0.7 \mathrm{Kz}$

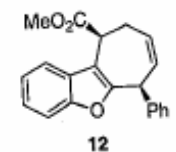

12

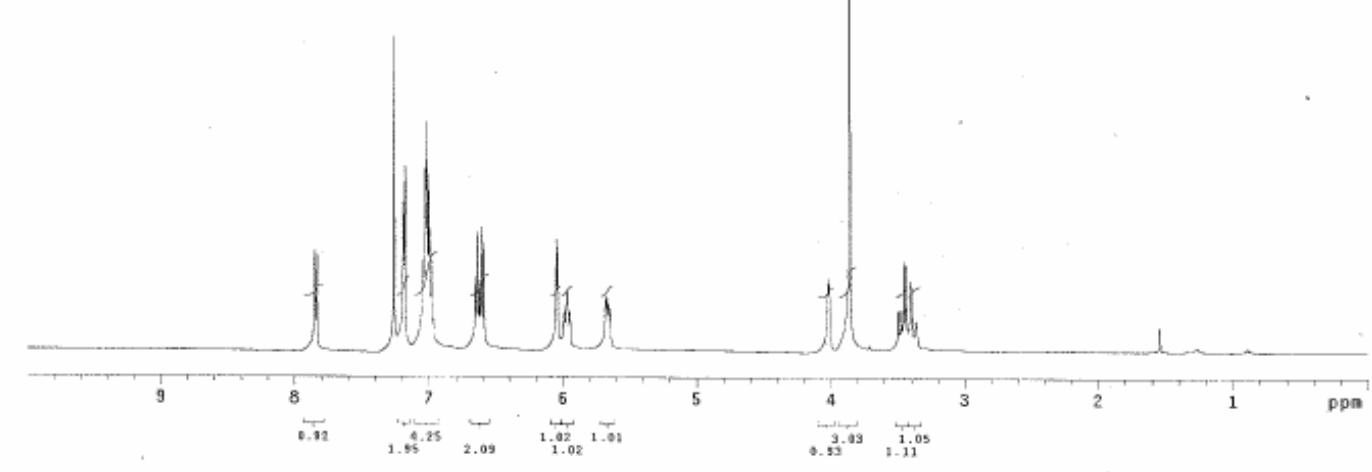

J01806-7-43-931207-C13

Pu1se saquencel s2pu
Solvent: cocis

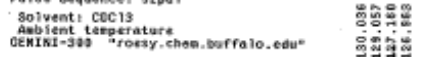

Ralax. delay S.en whe

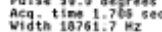

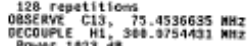

continucus 1y on

Lins becadention $1.0 \mathrm{~Hz}$

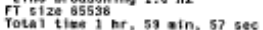
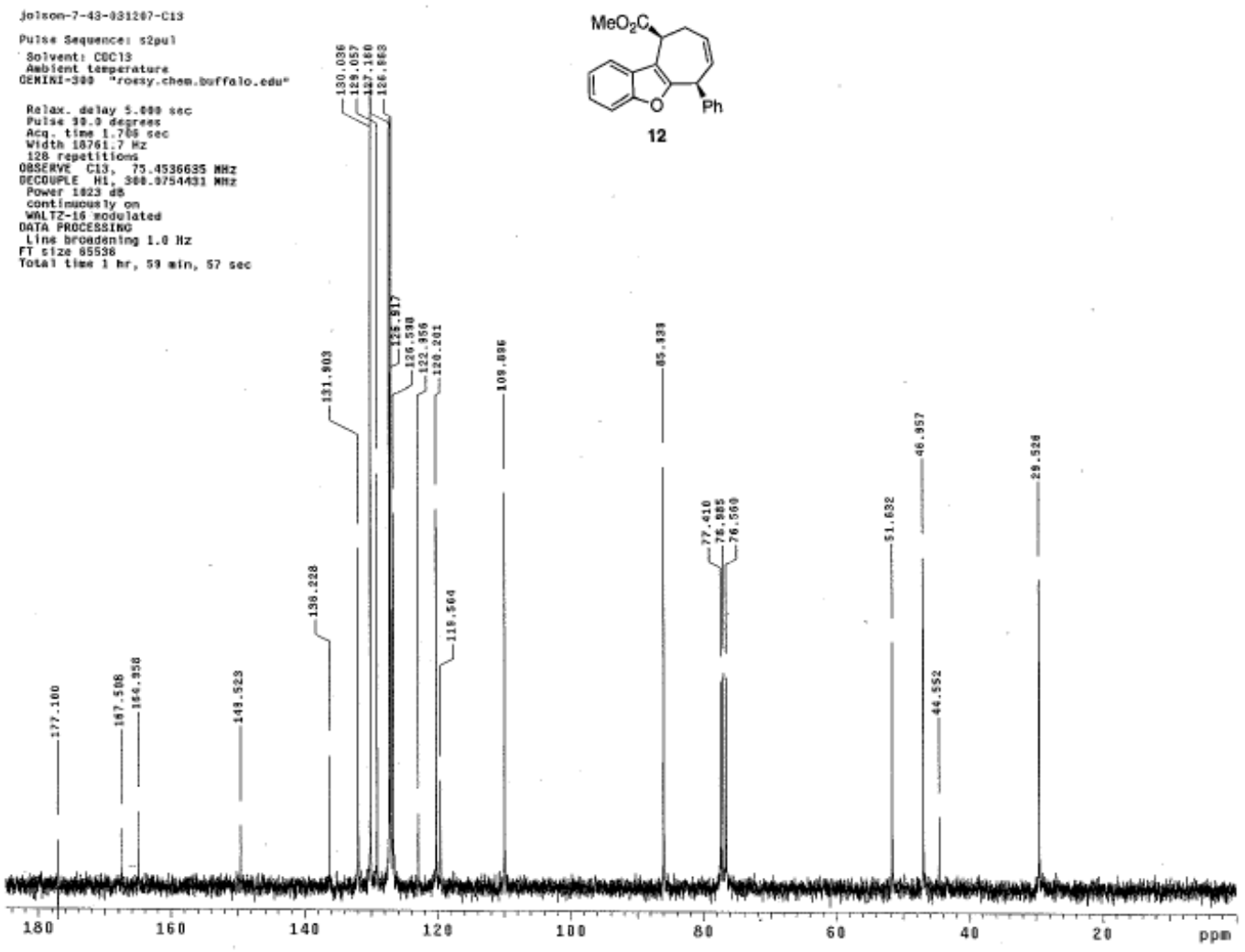

S-19 

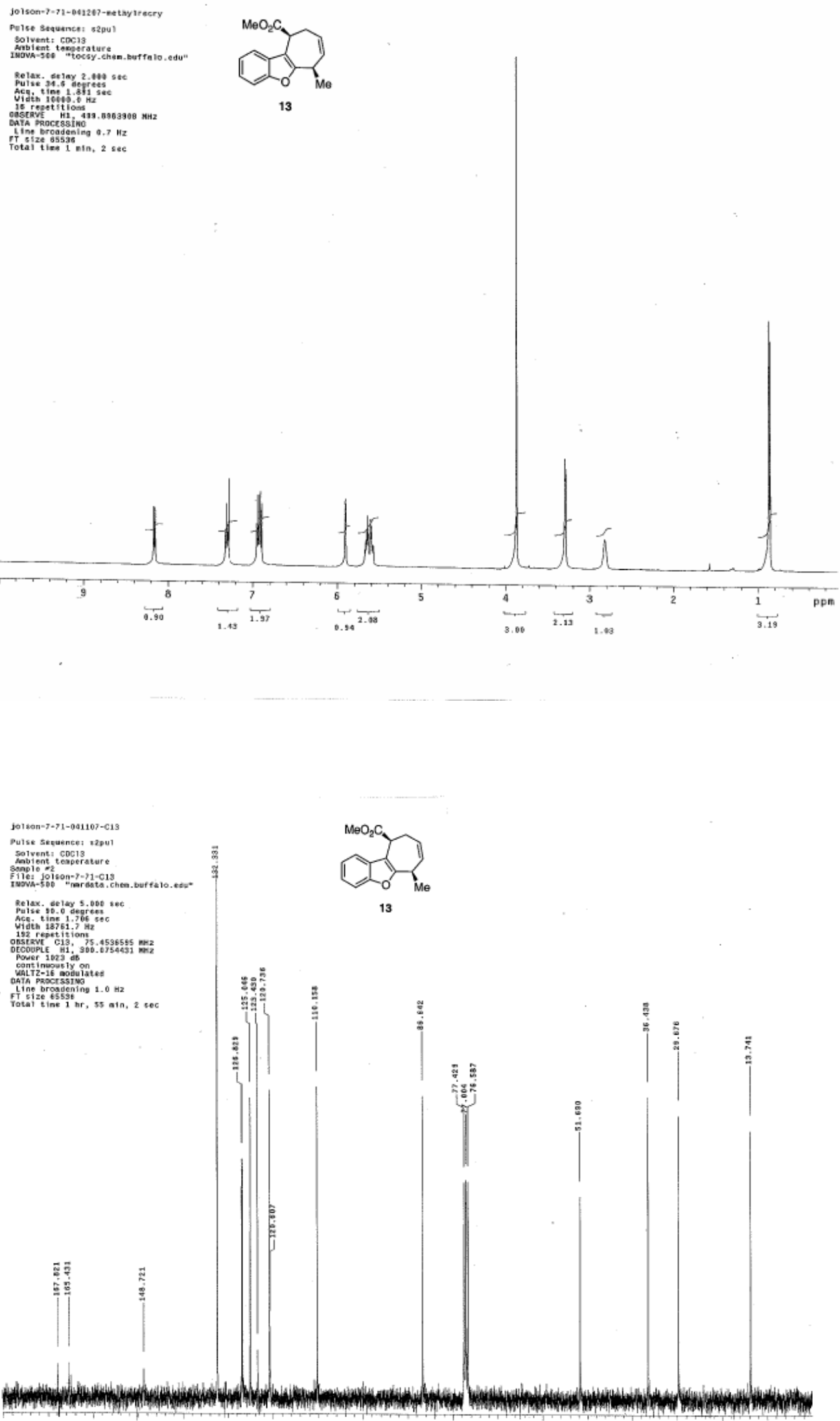

160

140

100

60

40 

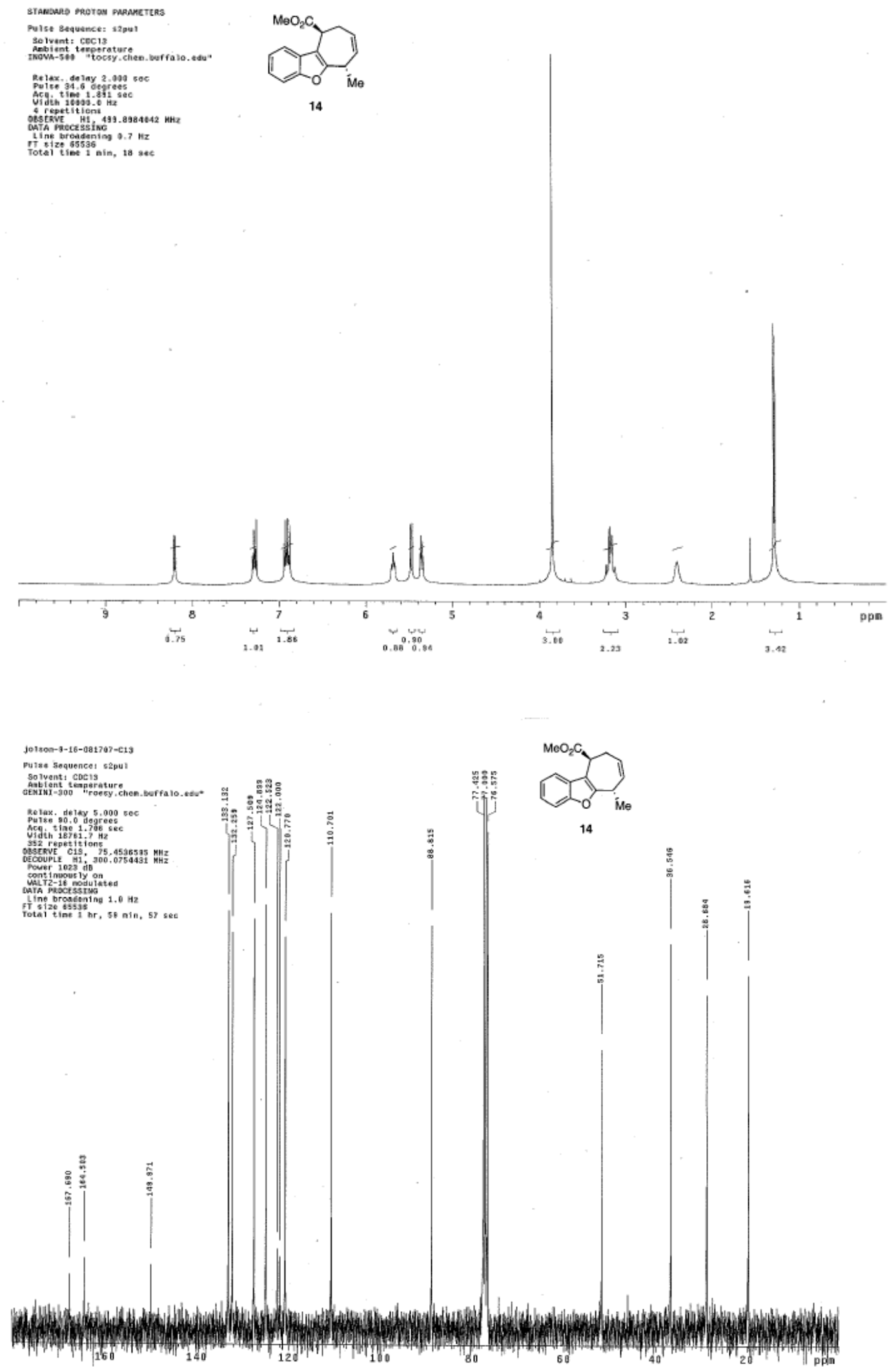
go 1506-9-11-colunnatiacthy

Pulse saquencel szมo

Solvent! coc1s

ralo.esu

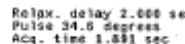

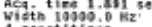

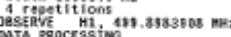

tine brosedening $6.7 \mathrm{Mz}$

FT size 555 ts

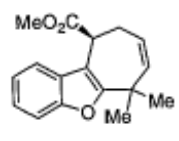

15

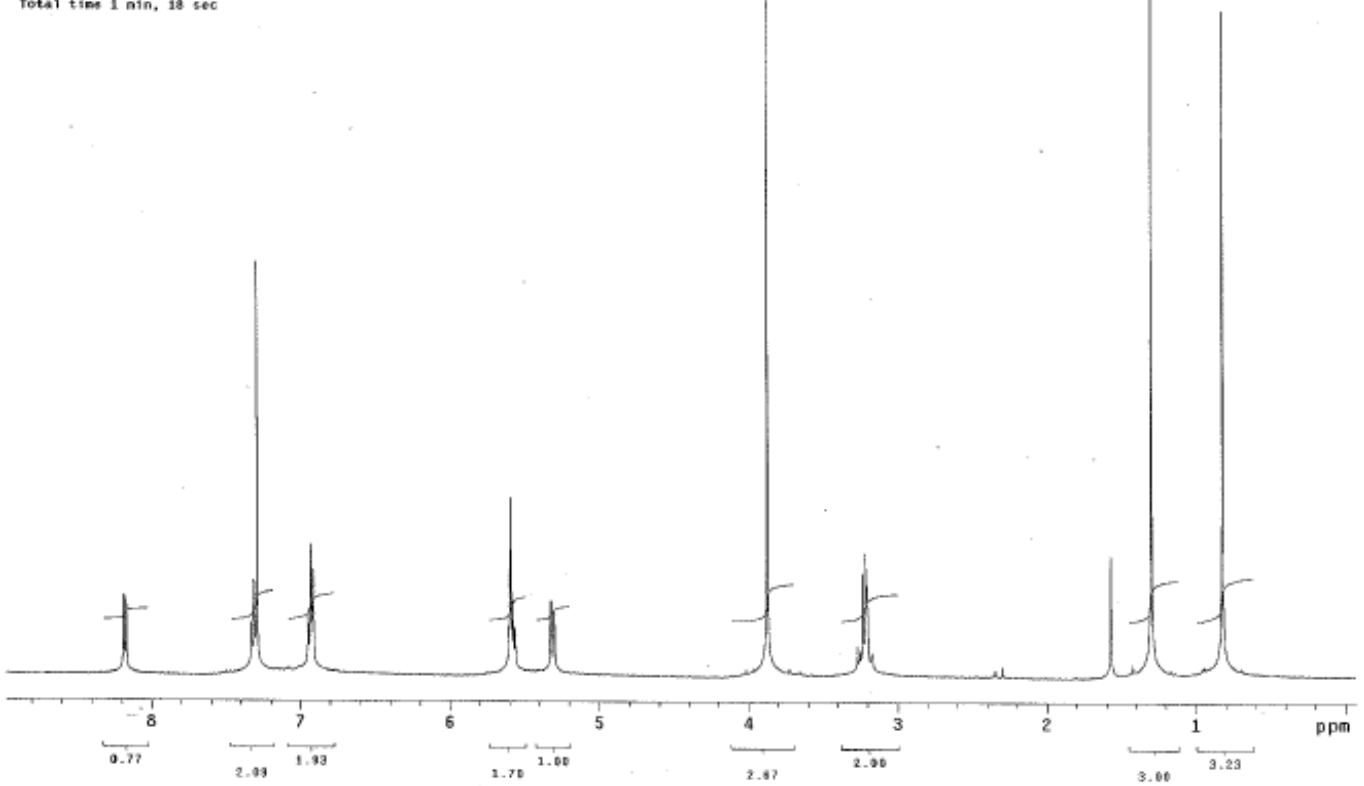

Jo1son-9-10-rearrangenentc1:

Pulse sequencet s2pul

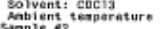

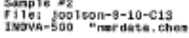

Rolax , delany 5.000 se
Pulbo 90.0 degrees

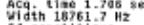

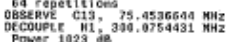

continuousty on

Totail tive 1 hr, ss asr, 2 sec

Mé 

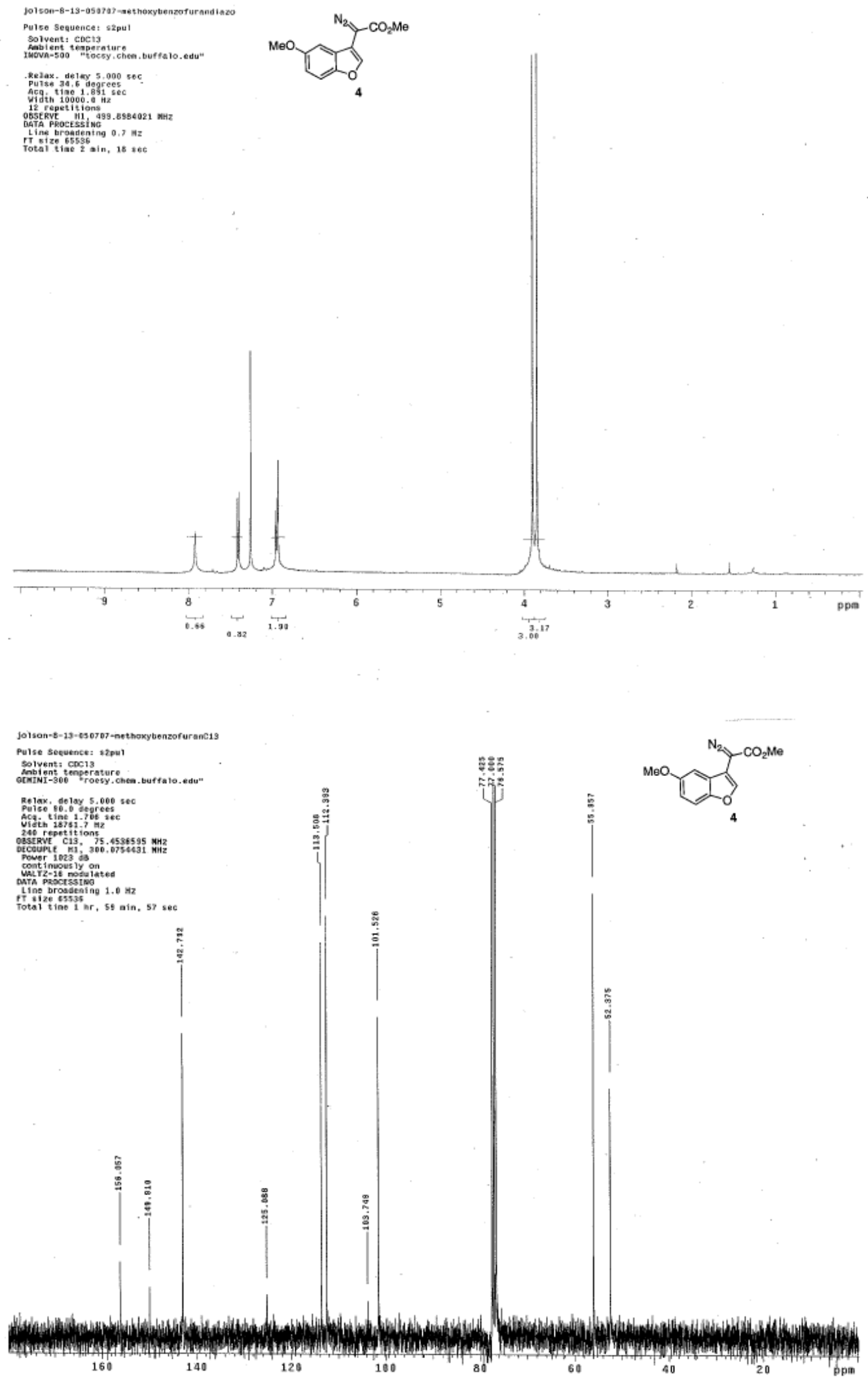

S-23 

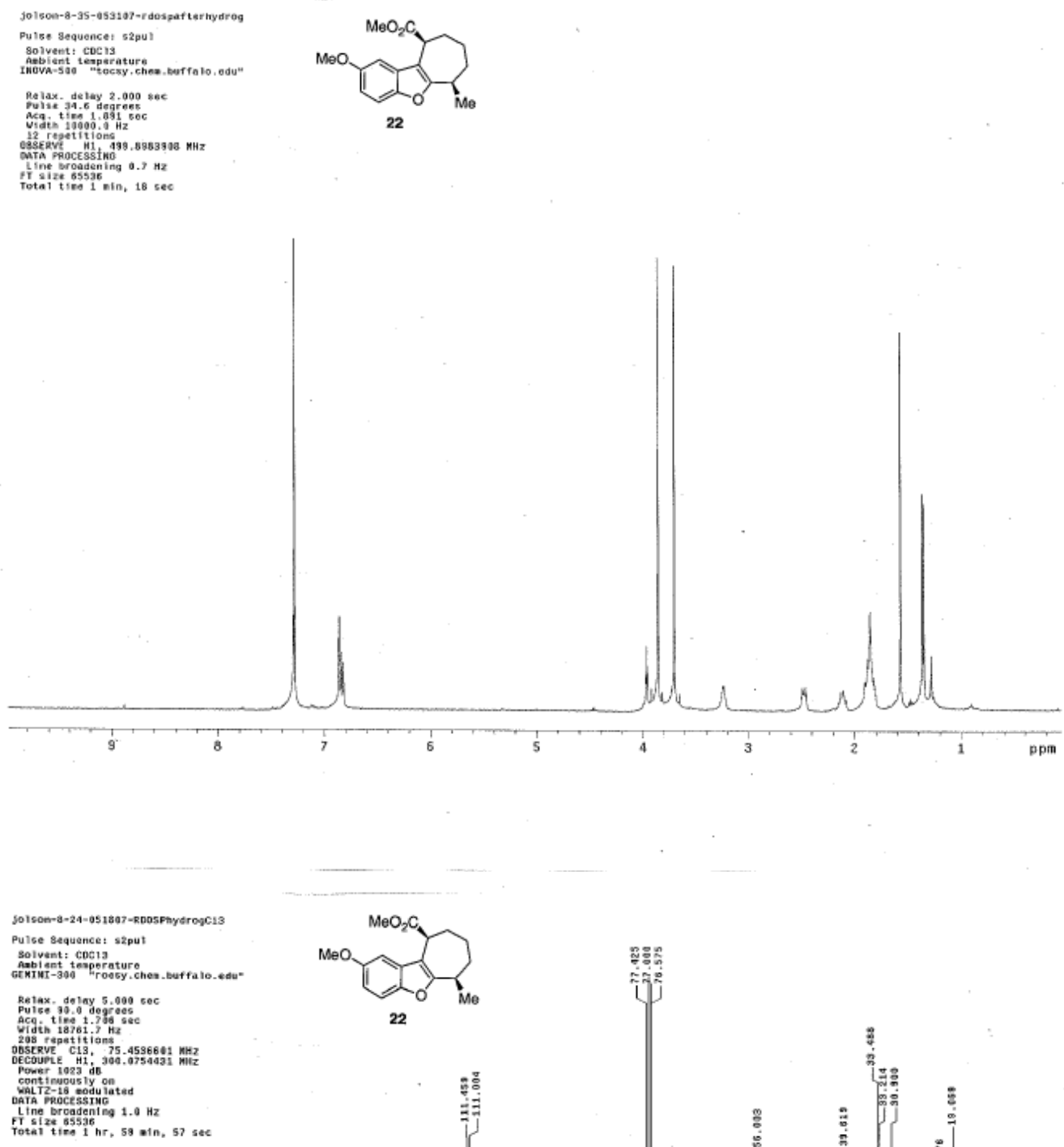

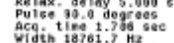

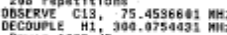

Mal T2-10 eodulatsd

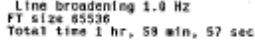

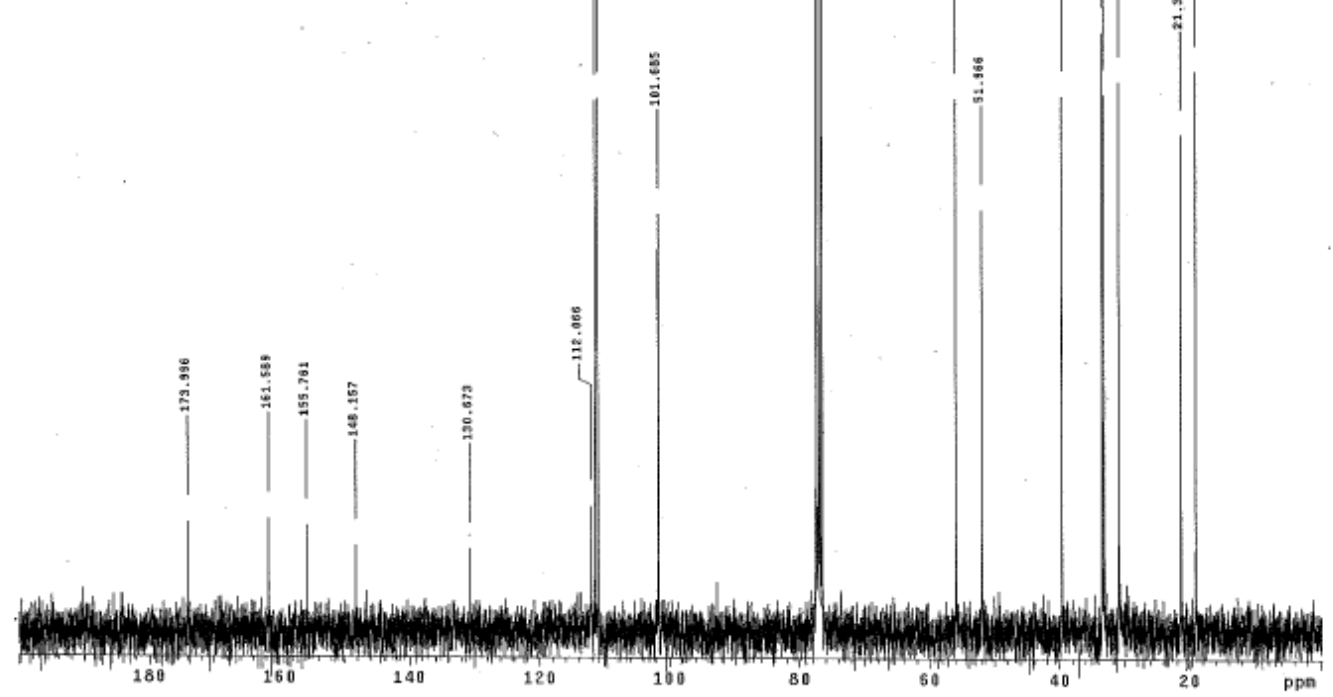



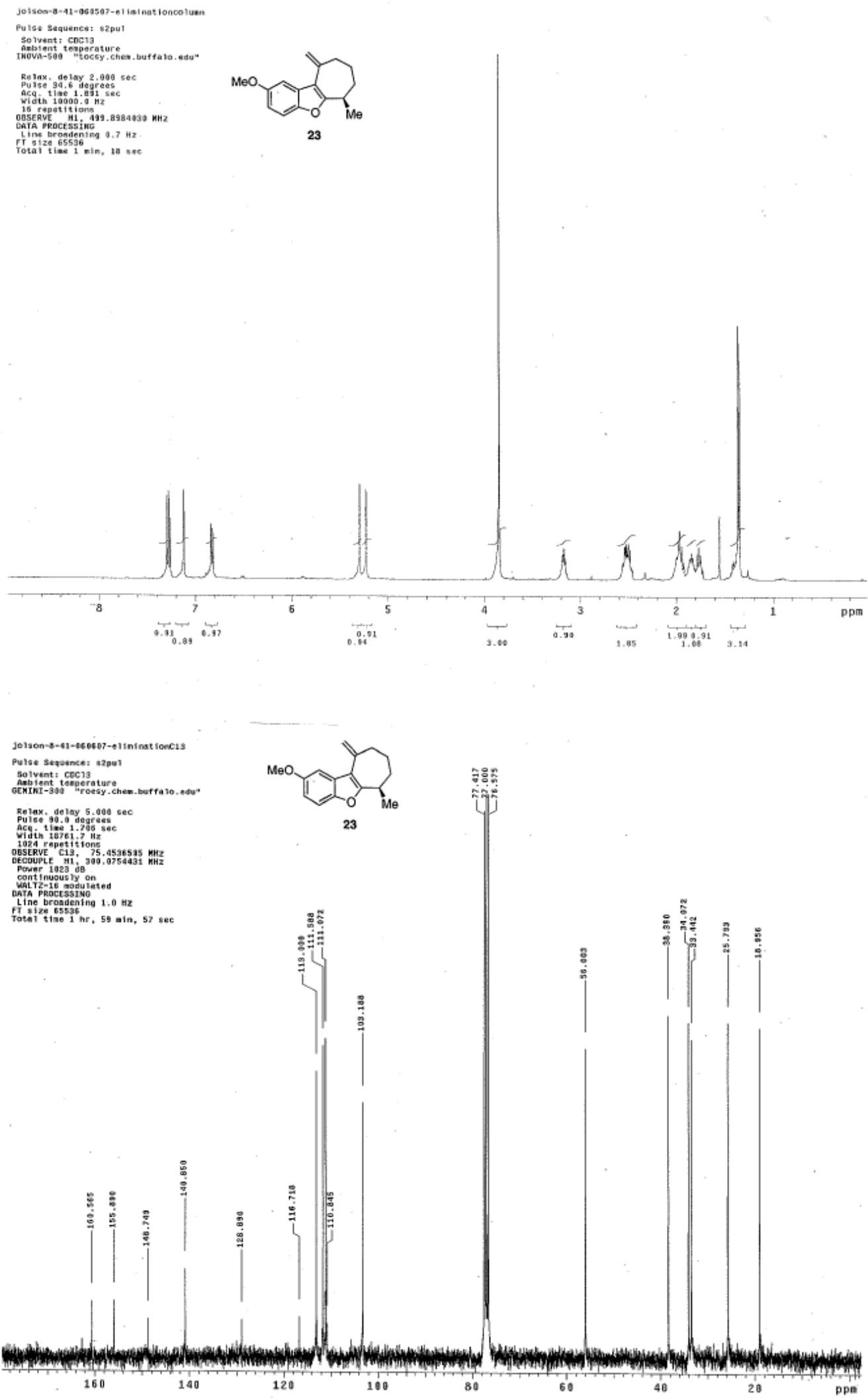
Solson-5-70-axi diat ivec leavageco luen Pulse Sequence: s2pul

Salvent

-500 "tocey . chen butfata. edu"

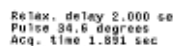

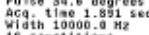

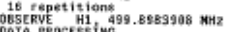

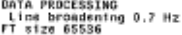

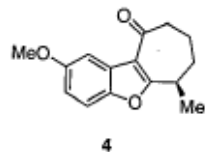

26 $6553650.18 \mathrm{sec}$

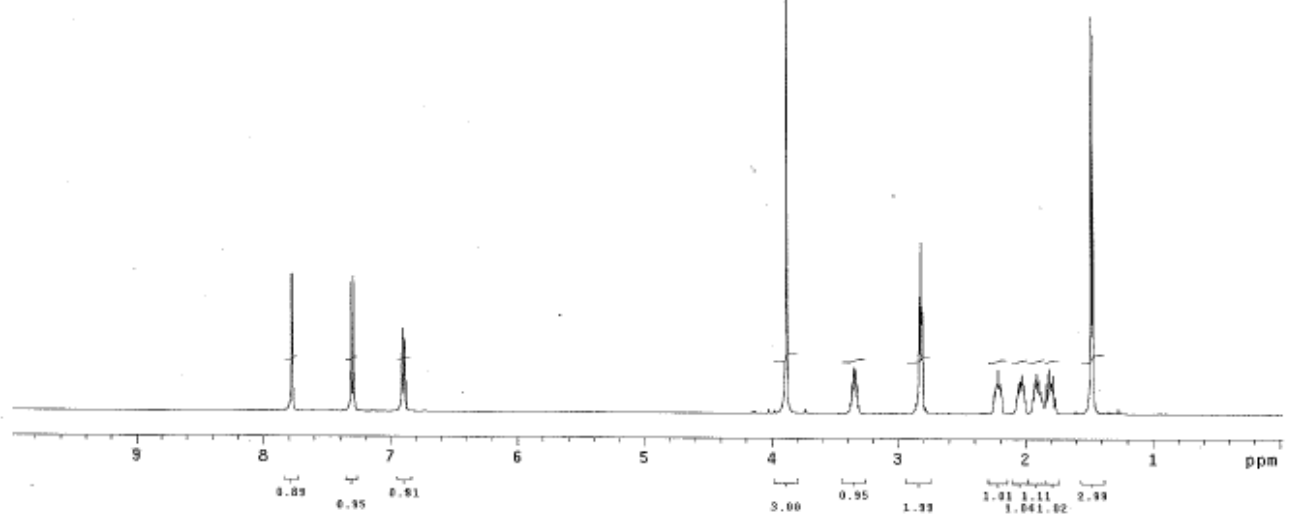

